\title{
Dynamics of carbon loss from an arenosol by a forest/vineyard land use change on a centennial scale
}

\author{
Solène Quéro ${ }^{1 *}$, Christine Hatté ${ }^{2}$, Sophie Cornu${ }^{1}$, Adrien Duvivier ${ }^{1}$, Nithavong Cam ${ }^{1}$, Floriane
}

5 Jamoteau $^{1,3}$, Daniel Borschneck ${ }^{1}$, Isabelle Basile-Doelsch ${ }^{1}$

${ }^{1}$ Aix Marseille Univ, CNRS, IRD, INRAE, CEREGE, Aix-en-Provence, France

${ }^{2}$ Laboratoire des Sciences du Climat et de l'Environnement, UMR 8212 CEACNRSUVSQ, Université Paris-Saclay, Gif-surYvette, France.

${ }^{3}$ CIRAD, Internal Research Unit (UPR) Recycling and Risk, Station de La Bretagne, Réunion, France

10 Correspondence to: Solène Quéro (quero@cerege.fr)

\begin{abstract}
Few studies have focused on arenosols with regard to soil carbon dynamics despite the fact that they represent 8\% of the world's soils and are present in key areas where food security is a major issue (e.g. in Sahelian regions). As for other soil types, land use changes (from forest or grassland to cropland) lead to a loss of substantial soil organic carbon (SOC) stocks and have a lasting impact on the SOC turnover. Here we quantified long-term variations in carbon stocks and their dynamics

15 in a $80 \mathrm{~cm}$ deep Mediterranean Arenosol that had undergone a land use change from forest to vineyard over more than 100 years ago. Paired-sites of adjacent plots combined with carbon and nitrogen quantification and natural radiocarbon $\left({ }^{14} \mathrm{C}\right)$ abundance analyses revealed a stock of $50 \mathrm{GtC} \mathrm{ha}^{-1}$ in the $0-30 \mathrm{~cm}$ forest soil horizon, which was reduced to $3 \mathrm{GtC}^{-1}$ after long-term grape cultivation. TOC in vineyard was dramatically low, with around $1 \mathrm{gC} \mathrm{kg}^{-1}$ and no vertical gradient as a function of depth. ${ }^{14} \mathrm{C}$ showed that deep ploughing $(50 \mathrm{~cm})$ in vineyard plot redistributed the remaining carbon both vertically and

20 horizontally. This remaining carbon was old carbon (compared to that of the forest), which had a C:N ratio characteristic of microbial OM and was probably stabilized within organomineral associations. Despite the drastic degradation of the OM pool in this Arenosol, this soil would have a high carbon storage potential if agricultural practices, such as grassing or organic amendment applications, were to be implemented within the framework of the 4 per 1000 Initiative.
\end{abstract}

\section{Introduction}

25 Arenosols account for $8 \%$ of the world's soils and are found mostly under desert, tropical and Mediterranean climatic conditions (FAO, 2014). They are silty-sandy or sandy soils, with less than $35 \%$ by volume of coarse elements and occur in layers about $100 \mathrm{~cm}$ deep (FAO, 2014). Surface carbon concentrations of arenosols range from $100 \mathrm{~g} \mathrm{~kg}^{-1}$ for the richest (Andreetta et al., 2013) to $1 \mathrm{~g} \mathrm{~kg}^{-1}$ for the poorest (Fourie et al., 2005; López-Piñeiro, 2013), with stocks in the 0-30 cm layer ranging from $15 \mathrm{tC} \mathrm{ha}^{-1}$ (Muñoz-Rojas et al., 2012) to more than $80 \mathrm{tC} \mathrm{ha}^{-1}$ (Marschner and Waldemar Wilczynski, 1991), with

$3080 \mathrm{tC} \mathrm{ha}^{-1}$ being the average for global soils (Mousset, 2014). As with other soil types, changes in arenosol land use patterns 
https://doi.org/10.5194/soil-2021-115

Preprint. Discussion started: 12 October 2021

(c) Author(s) 2021. CC BY 4.0 License.

(c) (i)

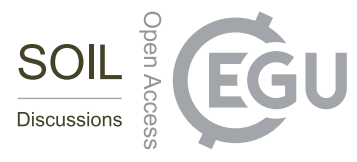

(from forest or grassland to cropland) can lead to a loss of carbon (Lal, 2004). Arenosols can also be considered as soils with storage potential suitable for meeting targets of the 4 per 1000 Initiative (Lal, 2004; Minasny et al., 2017). As these soils are present in key areas for future food production (FAO, 2018), understanding carbon dynamics in arenosols is therefore also a crucial societal challenge. Unfortunately, however, few studies to date have focused on this type of soil (Kögel-Knabner and Amelung, 2021).

Whatever the soil type, land use changes (forest or grassland to cropland) may lead to high and rapid loss of carbon by erosion, runoff and/or mineralisation $\left(\mathrm{CO}_{2}\right.$ release), of about 50\% in 10 years (Guillaume et al., 2021; Ramesh et al., 2019). Most of this loss occurs in the surface horizons $(0-30 \mathrm{~cm})$, which are very sensitive to disturbance $(\mathrm{Lal}, 2004)$, which explains why most studies generally focus on topsoils (Baker et al., 2007). Land use changes also affect deep stocks representing a significant

40 amount of carbon, although quantitatively less than at the surface (Angers and Eriksen-Hamel, 2008; Basile-Doelsch et al., 2009; Poeplau and Don, 2013; Wang et al., 1999). Therefore, it would be essential to gain insight into the dynamics at the profile scale, not only at the agronomic horizon scale.

Institutional experimental sites with temporal monitoring have plots that are highly suitable for studying the impact of cultivation. However, experiments lasting more than 50 years are uncommon and generally there are no equivalent plots in old-growth forests (i.e. where the soil has not been disturbed by cultivation for at least 100 years). Apart from these experimental sites, the paired-site study strategy is highly relevant (Eldon and Gershenson, 2015). A site pair is defined as two plots with different uses on the same soil, under the same climatic conditions, on the same bedrock, and on a flat topography. However, as these conditions are difficult to meet, few studies have been carried out on pairs of soils in strict compliance with the above criteria, let alone over a long period of time to assess significant differences in carbon content between cultivated

50 and forest soils. In the metanalysis of Eldon \& Gershenson (2015), for example, the study times did not exceed 50 years. Balesdent et al. (2018) studied paired sites with a change in vegetation from $\mathrm{C}_{3}$ to $\mathrm{C}_{4}$, or vice versa, to assess the age of deep carbon stocks. This is an efficient method but only applicable to specific conditions (difference in ${ }^{13} \mathrm{C}$ isotopic signature between two successive vegetation types). Otherwise ${ }^{14} \mathrm{C}$ may be applicable to any system to assess the impact of cultivation on carbon dynamics at the decadal (or longer) scale as it is a function of carbon age (Trumbore, 2009). As early as 1993, a few

55 researchers used ${ }^{14} \mathrm{C}$ in a land use change context (Harrison et al., 1993; Trumbore, 1993), but since then few studies have followed suite. For example, only 3 of the 789 soil profiles documented in papers in the International Soil Radiocarbon Database (Anon, 2020; Lawrence et al., 2020) mention land use change (Dümig et al., 2008; James et al., 2019; Monreal et al., 1997). Cultivation mainly affects young (short turnover) carbon pools at the surface by promoting their mineralisation, but more stable (long turnover) carbon pools may also be impacted via their transfer to carbon pools with faster turnover (Poeplau

60 and Don, 2013), thus leading to overall ageing of soil organic matter (OM), at least at the surface (Wang et al., 1999).

Land use change affects carbon stocks and dynamics, but agricultural practices also have an effect. Surface $(0-30 \mathrm{~cm})$ or deep (> $50 \mathrm{~cm}$ ) ploughing, in particular, as carried out in vineyards, disturbs the vertical and horizontal distribution of carbon (Dimassi et al., 2014; Mary et al., 2020). ${ }^{14} \mathrm{C}$ is often used in studies to assess carbon dynamics in soils. However, few authors refer to the heterogeneity of the ${ }^{14} \mathrm{C}$ content within the same layer (van der Voort et al., 2016). Only two paper (Chiti et al., 
65 2016; van der Voort et al., 2016) in the International Soil Radiocarbon Database (Anon, 2020; Lawrence et al., 2020) dealt with single-layer heterogeneity and neither of them considered cultivated soils. The main obstacle to the use of ${ }^{14} \mathrm{C}$ is the high cost of analysis, which often warrants a single measurement. Samples can be pooled into a single composite sample to overcome this heterogeneity problem (Jiang et al., 2020). This is why—despite being essential in a tillage context—few studies to date have focused on intra-horizon variability.

70 Finally, although arenosols lose a lot of carbon during cultivation (Fourie et al., 2005; López-Piñeiro, 2013), they have a high storage potential. Experiments implementing storage practices on arenosols (Kazlauskaite-Jadzevice et al., 2019) documented an increase of 40.2 to $45.6 \mathrm{tha}^{-1}(+13.4 \%)$ and 39.4 to $49.0 \mathrm{t} \mathrm{ha}^{-1}(+24.4 \%)$ in soil organic carbon stock (SOC stock) in the 0-30 cm soil layer in 20 years following cropland abandonment and a grassland management change, respectively. Arenosols, which have very low carbon stocks in cultivated systems, thus seem to be good candidates for the 4 per 1000 (4p1000) Initiative.

This study was therefore carried out to highlight the impact of the establishment and management of a vineyard on an arenosol, as well as its consequences on the carbon dynamics at soil layer and entire soil profile scales. It also aimed to highlight links between the degree of biotransformation of OM by the microbial compartment and its age, and finally, to discuss the storage potential of arenosols with respect to the 4 p1000 criteria. We thus based our study on paired soils, measuring carbon contents

80 and stocks, vertical and intra-horizon heterogeneity of carbon as measured by ${ }^{14} \mathrm{C}$, and correlating the $\mathrm{C}: \mathrm{N}$ ratio and radiocarbon $\left(\mathrm{F}^{14} \mathrm{C}\right)$. Finally, we applied a rate of carbon incorporation in our cultivated arenosol according to the proportions and rate put forward in the remediation study of Kazlauskaite-Jadzevice et al. (2019).

\section{Materials and methods}

\subsection{Study area}

85 The study site was located at Plan de la Tour, in the Maures massif (France), under a Mediterranean climate: $\quad-3^{\circ} \mathrm{C}<\mathrm{T}_{\mathrm{Winter}}$ $<18^{\circ} \mathrm{C}$ and $\mathrm{T}_{\text {Summer }}>22^{\circ} \mathrm{C}, \mathrm{P}_{\text {driest month }}<40 \mathrm{~mm}$ (Rubel and Kottek, 2010). The soil was a poorly differentiated arenosol on granite. The site consisted of two plots on a flat landscape: one in a forest and the other in a vineyard. An analysis of aerial photographs and cadastral maps (from 1813 to present day) showed that these two plots had a history of continuous soil use for at least $\sim 100$ years in the case of the forest (with an age of 91 years, as measured by dendrochronology on a cork oak) and 90 more than 150 years in the case of the vineyard (Fig.B1). Additional field work ruled out the effects of terracing at the selected sampling spots. The vineyard plot had undergone vine uprooting and deep ploughing $(\sim 50 \mathrm{~cm})$ every 70 years on average. The last ploughing was carried out between 1998 and 2003. The soil was bare between rows (Fig.1 and Fig.B1). 


\subsection{Sampling}

95 Two pits were dug down to the underlying granite: the forest pit $\left(43^{\circ} 19^{\prime} 37.35\right.$ "N, $6^{\circ} 32^{\prime} 12.89$ "E) was $70 \mathrm{~cm}$ deep and the

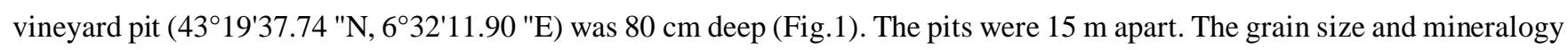
were similar at both sites (Fig.B2 and Fig.B3). Three faces were sampled per pit (A, B and C). Soil cylinders were taken from the three faces in the vineyard pit $(100 \mathrm{ml})$ and from two faces in the forest pit $(1230 \mathrm{ml}$, only below $20 \mathrm{~cm})$ to determine the bulk density. Above $20 \mathrm{~cm}$, in the forest soil, the water measurement technique was preferred to the cylinder technique due to

100 the high abundance of tree roots. Bulk density samples were oven dried at $105^{\circ} \mathrm{C}$ for 3 days before weighing. The profile samples were air-dried $\left(25^{\circ} \mathrm{C}\right)$ for 1 week, sieved $(2 \mathrm{~mm})$ and ground in a planetary mill $(50 \mathrm{~g}$ for $5 \mathrm{~min}$, including $1 \mathrm{~min}$ reverse, at $400 \mathrm{rpm}$ ) down to $<200 \mu \mathrm{m}$ and quartered. For the ${ }^{14} \mathrm{C}$ analysis, a $3 \mathrm{~g}$ composite sample (i.e. a mix of $1 \mathrm{~g}$ of $\mathrm{A}, \mathrm{B}$ and C) was prepared for each depth range. To test the intra-horizon variability, $5-10 \mathrm{~cm}$ and $40-50 \mathrm{~cm}$ samples in the forest and vineyard, and also 50-60 cm samples in the vineyard (below the ploughing sole) were selected for further analyses (Fig.1,

105 Table $\mathrm{C} 1$ and $\mathrm{C} 2$ ). This variability was used to extrapolate the variability at all depths for in the vineyard and forest.

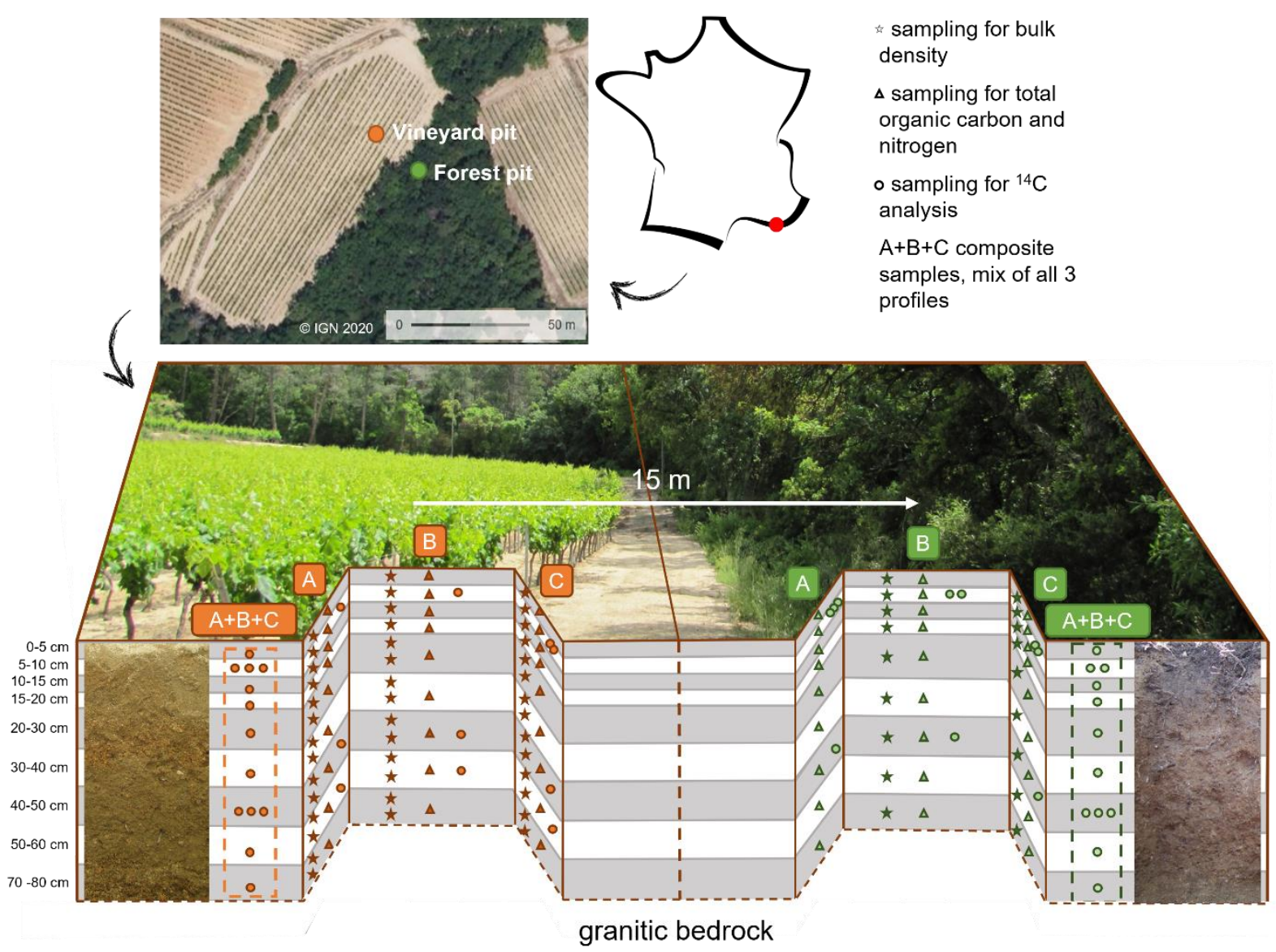


Figure 1: Scheme of the pits and sampling in the Brugassières arenosol under a Mediterranean climate: left, vineyard site (orange symbols); right, forest site (green symbols). A, B and C represent the three different sampled sides of each pit. Symbols indicate the sampling and analysis for each sampled layer: stars, sampling in cylinders for bulk density; triangles, sampling for total organic carbon and total nitrogen (TOC, TN), granulometry and mineralogy; circles, sampling for analysis in 14C; $(A+B+C)$ represent composite samples resulting from the mixture of samples from the three faces at equal proportions. The aerial photo was from Géoportail website (https://www.geoportail.gouv.fr), the other photos were from personal sources.

\subsection{Methods}

\section{2.3.1 Carbon and nitrogen measurement, and stocks calculation}

Carbon and nitrogen contents were measured by dry combustion with an elemental analyser (NF ISO 10694 and 13878 , respectively). Soil organic carbon stocks (SOC stock) were calculated according to Eq. (1):

SOC stock $=B D * T O C * e * 10$

Carbon stocks are expressed in $\mathrm{t} \cdot \mathrm{ha}^{-1}$, carbon content (TOC) in $\mathrm{g} \cdot \mathrm{kg}^{-1}$, bulk density (BD) in $\mathrm{g} \cdot \mathrm{cm}^{-3}$ and layer thickness (e) in

$\mathrm{cm}$. A correction (equation 2) was then applied in order to compare carbon stocks at equivalent mass and thus eliminate differences in bulk density between the two sites for the same depth (Ellert and Bettany, 1995; Poeplau et al., 2017; Poeplau and Don, 2013) Eq. (2) :

SOC stock cor $=$ SOC stock $-\left(\frac{M_{\text {sample }}-M_{e q}}{V} *\right.$ TOC $\left.* e * 10\right)$

Here $\mathrm{V}$ is a predefined volume of $1 \mathrm{~cm}^{3}, \mathrm{M}_{\text {sample }}$ is the sample mass in $\mathrm{g}$, with $\mathrm{M}_{\mathrm{sample}}=\mathrm{BD} * \mathrm{~V}$ and $\mathrm{M}_{\mathrm{eq}}$ being the equivalent mass in $\mathrm{g}$, which corresponds to the mass of the least dense sample (i.e forest sample) between the two compared sites, for the same depth.

\subsubsection{Carbon and nitrogen measurement, and stocks calculation}

The sample ${ }^{14} \mathrm{C}$ contents were evaluated on raw samples (no chemistry applied). The most carbon-rich samples (forest <40 cm) were measured on the solid source of the ECHoMICADAS (Synal et al. 2007, Tisnérat-Laborde et al., 2015) or via the gas source. Organic carbon of the carbon-rich samples was first transformed into graphite on AGE3 (Wacker et al., 2010). The analyzed carbon quantity ranged from 24 to $86 \mu \mathrm{g}$ of carbon in the vine profiles samples, 87 to 89 and 983 to $1000 \mu \mathrm{g}$ of carbon in the forest profiles samples measured through the gas source and the solid source, respectively. The range of variation of the analytical error, expressed as $\mathrm{F}^{14} \mathrm{C}$, was between 0.002 and 0.014 and decreased with increasing carbon mass (Fig.E1). The radiocarbon data are expressed in modern $\mathrm{F}^{14} \mathrm{C}$ fraction, as recommended by Reimer et al. (2004). The difference between

135 the highest and lowest $\mathrm{F}^{14} \mathrm{C}$ values for the same depth is expressed by $\Delta \mathrm{F}^{14} \mathrm{C}$. However, since many authors have used the $\Delta^{14} \mathrm{C}$ or conventional radiocarbon age to express ${ }^{14} \mathrm{C}$ (Reimer et al., 2004; Stuiver and Polach, 1977), the data expressed in $\Delta^{14} \mathrm{C}$ and conventional age are shown in Fig.E2 to facilitate comparison. All equations for the different units can be found in appendix A. 


\section{Results}

\section{$140 \quad 3.1$ Carbon content, C:N ratio and stocks}

The results of the carbon content profiles are presented in Fig.2a. Under the forest, carbon content and variability were high at the surface, with $33-56 \mathrm{~g} \mathrm{~kg}^{-1}$ in the 0-5 cm layer ( \pm 9), but it decreased with depth down to $1.89-2.50 \mathrm{~g} \mathrm{~kg}^{-1}$ in the 0-60 cm layer $( \pm 0.06)$. Under vines, the carbon content was comparatively very depleted and equivalent in the 3 profiles throughout the depth. At the surface $(0-5 \mathrm{~cm})$, the TOC ranged from 0.9 to $2.4 \mathrm{~g} \mathrm{~kg}^{-1}( \pm 0.8)$, and at depth $(70-80 \mathrm{~cm})$ it ranged from 0.34

145 to $0.82 \mathrm{~g} \mathrm{~kg}^{-1}( \pm 0.29)$. The TOC values under vines were extremely low compared to those under the forest (23-fold lower than under the forest in the 0-5 cm layer) and this depletion was even observed at depth. The C:N ratios are presented in Fig. $2 \mathrm{~b}$. Under the forest, the average C:N ratio was high, i.e. around 16 in the $0-5 \mathrm{~cm}$ layer, and decreased with depth to 10 in the 60 $70 \mathrm{~cm}$ layer. The C:N ratio under vines was twice as low as noted in the forest surface horizon $(8 \pm 3$ versus 16 in the $0-5 \mathrm{~cm}$ layer), and there were variations in this ratio up to $50 \mathrm{~cm}$ depth. Beyond this depth, the vineyard profile became similar to that under the forest. Finally, the cumulative stocks at $30 \mathrm{~cm}$ depth are represented in Fig.2c, and the forest soil contained $50 \mathrm{tC}$ ha ${ }^{-1}$ while the vineyard soil contained only $3 \mathrm{tC} \mathrm{ha}^{-1}$.

\subsection{Radiocarbon}

The radiocarbon profile results are presented in Fig.2d. Young carbon was detected in the forest profile, i.e. younger than the 1960 bom peak $\left(\mathrm{F}^{14} \mathrm{C}>1\right)$, at the surface. The carbon age then increased with depth $\left(\mathrm{F}^{14} \mathrm{C}<1\right.$ around $\left.40 \mathrm{~cm}\right)$. This was a conventional undisturbed soil profile (Jreich, 2018; Mathieu et al., 2015; van der Voort et al., 2016), which shows a 'belly' shape curve between 5 and $20 \mathrm{~cm}$ depth. This belly shape curve corresponded to the penetration of the ${ }^{14} \mathrm{C}$ signal of the bomb peak in the profile. Concerning the variability in a single soil layer, $\mathrm{F}^{14} \mathrm{C}$ ranged from 1.095 to $1.124\left(\Delta \mathrm{F}{ }^{14} \mathrm{C}=0.029\right)$ at the surface $(5-10 \mathrm{~cm})$. Meanwhile, at depth $(40-50 \mathrm{~cm}), \mathrm{F}^{14} \mathrm{C}$ ranged from 0.974 to $1.005\left(\Delta \mathrm{F}^{14} \mathrm{C}=0.031\right.$; Fig. $\left.2 \mathrm{~d}\right)$.

Conversely, the vineyard profile revealed the presence of old carbon from the surface to the bottom of the pit $\left(\mathrm{F}^{14} \mathrm{C}=0.893\right.$ at

160 the surface and 0.990 at depth), despite the heterogeneity within the horizons (one point with an $\mathrm{F}^{14} \mathrm{C}>1$, at $40-50 \mathrm{~cm}$ ). The variation pattern in the profile was not progressive from the soil surface to the depth, contrary to the pattern noted in the forest profile. Under vines, the intra-horizon variability was much more marked than under the forest. In the $0-10 \mathrm{~cm}$ layer, $\mathrm{F}^{14} \mathrm{C}$ ranged from 0.880 to $0.969\left(\Delta \mathrm{F}^{14} \mathrm{C}=0.089\right)$, and from 0.909 to $1.081\left(\Delta \mathrm{F}^{14} \mathrm{C}=0.172\right)$ at $40-50 \mathrm{~cm}$ depth. 
https://doi.org/10.5194/soil-2021-115

Preprint. Discussion started: 12 October 2021

(c) Author(s) 2021. CC BY 4.0 License.

a.

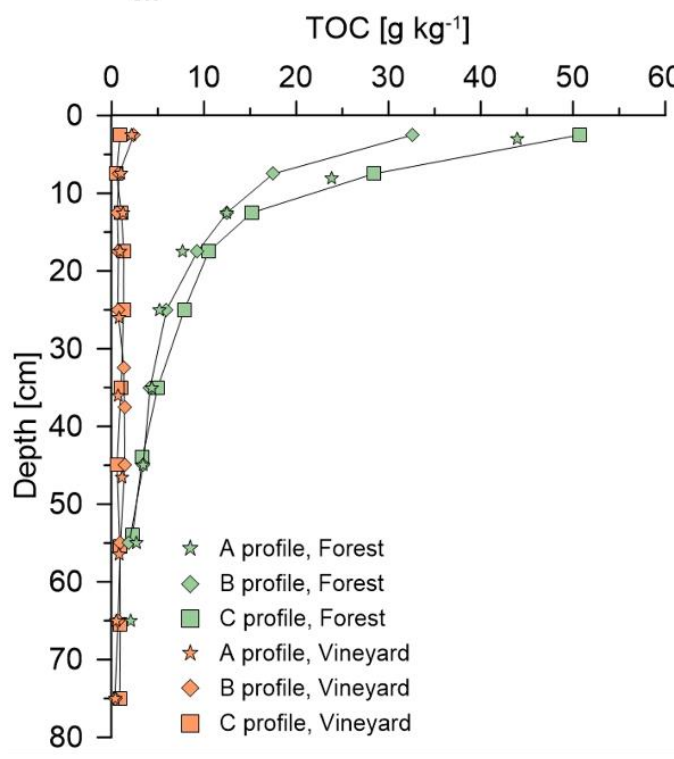

c.

Corrected cumulative SOC stock [Mg ha-1] b.

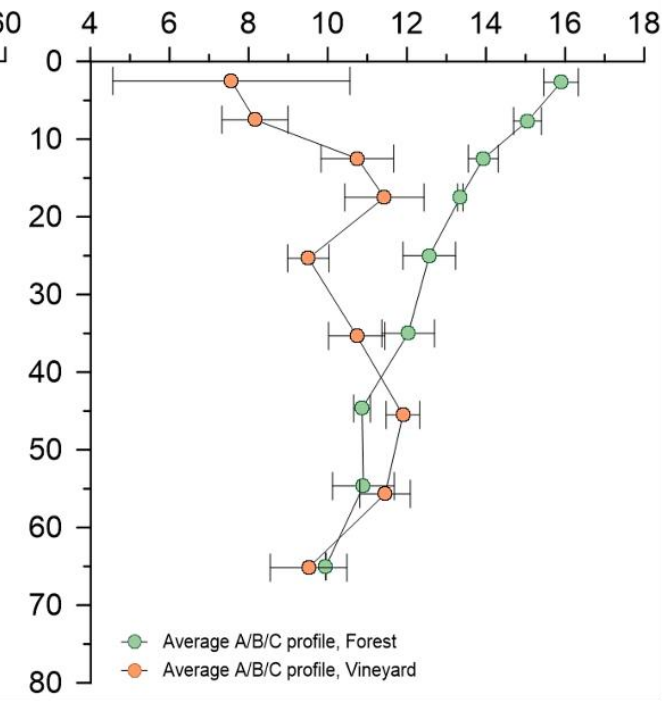

d.

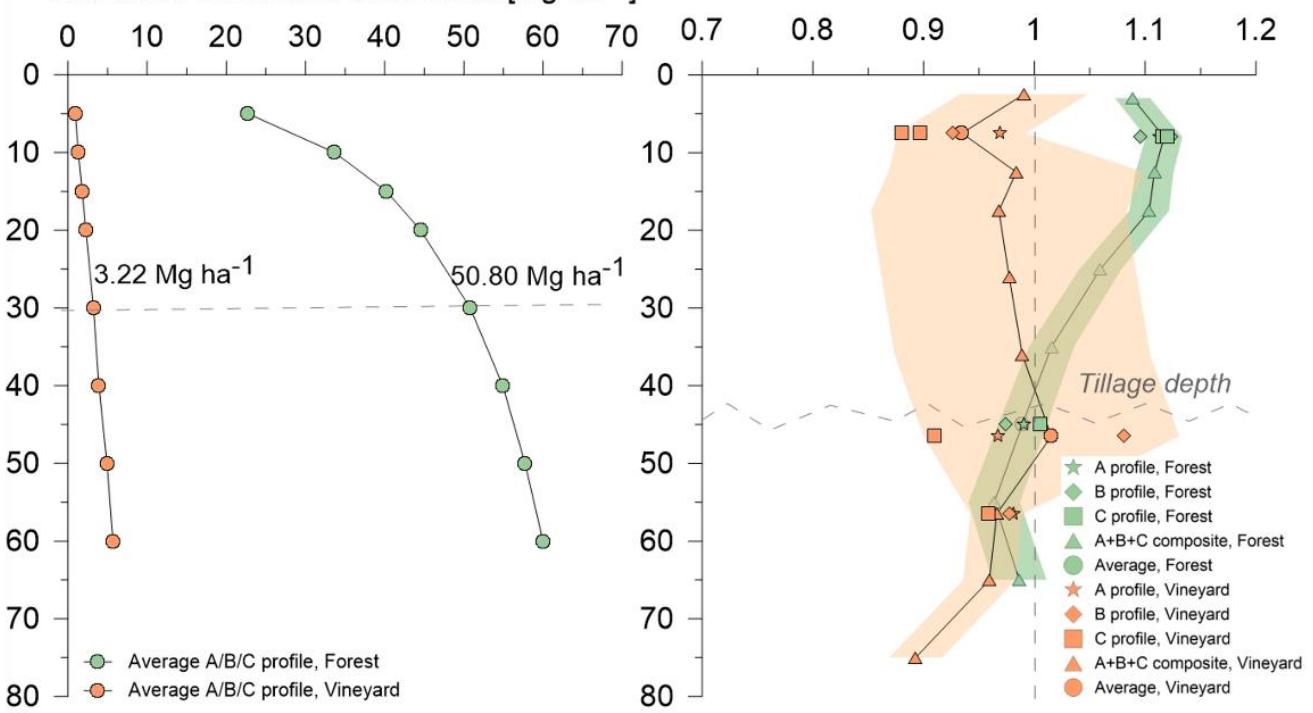

Figure 2: TOC variations (a), C:N ratio (b), cumulative stocks corrected for equivalent mass (c) and $\mathrm{F}^{14} \mathrm{C}$ profiles (d) as a function of depth, under vines (orange) and under forest (green), for an arenosol under a Mediterranean climate. The $\mathrm{F}^{14} \mathrm{C}$ measurement variability (d) is represented by green (forest) and orange (vine) bands. 


\section{Discussion}

\subsection{Comparison with Mediterranean arenosols}

Under the forest, the TOC profiles ( $22 \pm 5 \mathrm{~g} \mathrm{~kg}^{-1}$ in the $0-20 \mathrm{~cm}$ layer and $3.94 \pm 0.25 \mathrm{~g} \mathrm{~kg}^{-1}$ in the $30-50 \mathrm{~cm}$ layer) obtained for topsoil and subsoil were comparable to those obtained for other arenosols under Mediterranean climatic conditions (Figure 3a) (Andreetta et al., 2013; Caravaca et al., 2002; Fierro et al., 2007; Pinzari et al., 1999; Vittori Antisari et al., 2016). However, to our knowledge, very few data are available beyond $30 \mathrm{~cm}$ soil depth. For comparison, we only identified 5 references of studies concerning arenosols under grapevines in Mediterranean climatic conditions. The Brugassières arenosol was found to be among the soils with the lowest of organic carbon content values (Figure 3b). This trend was visible in surface soils as well as at depth. Some arenosols under vines reportedly had low carbon contents comparable to those in the soil studied here, both at the surface and at depth (Fourie et al., 2005; López-Piñeiro, 2013). The arenosol in this study, although very depleted in C, does not seem to represent a unique case of OM depletion after arenosol vineyard cultivation.

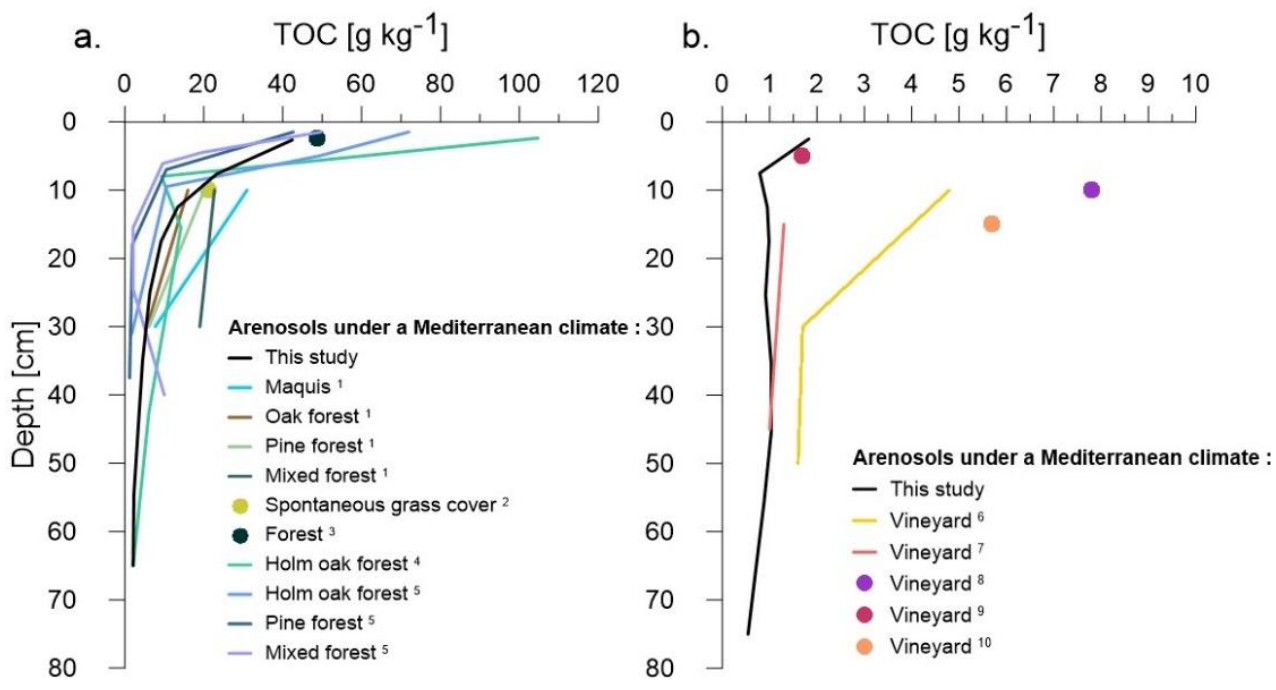

Figure 3: TOC comparison between the Brugassières arenosol and other forest arenosols (a) and vineyard arenosols (b) under a Mediterranean climate (1) Pinzari et al., (1999); (2) Caravaca et al., (2002) ; (3) Fierro et al., (2007) ; (4) Andreetta et al., (2013) ; (5) Vittori Antisari et al., (2016) ; (6) Conradie, (2001) ; (7) Fourie et al., (2005) ; (8) Okur et al., (2009) ; (9) López-Piñeiro, (2013) ; (10) Nogales et al., (2019). Data available in Table D1.

\section{4.2 Drastic carbon stock loss: a combination of land use change / agricultural practices / unfavourable soil texture}

These very low carbon contents in the vineyard resulted in a 12 -fold lower carbon stock in the vineyard than in the forest throughout the profile (e.g. in the 0-30 cm layer, the SOC stock was $3.2 \mathrm{t} \mathrm{ha}^{-1}$ in the vineyard compared to $50.8 \mathrm{t} \mathrm{ha}^{-1}$ in the forest) (Fig.2c). Arenosol carbon stocks under the forest, in the 0-30 cm layer, were lower than stocks under the forest irrespective of the soil type ( $80 \mathrm{t} \mathrm{ha}^{-1}$, Mousset, (2014)). The difference between the national forest average and that of the

190 studied forest was: $80-50.8=29.2 \mathrm{t} \mathrm{ha}^{-1}$. This suggests that arenosol carbon stocks under vines were lower than the average in French vineyards (30 $\mathrm{t} \mathrm{ha}^{-1}$, Mousset, 2014). The difference between the national mean and that of the studied vineyard was: 
https://doi.org/10.5194/soil-2021-115

Preprint. Discussion started: 12 October 2021

(c) Author(s) 2021. CC BY 4.0 License.

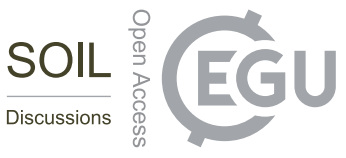

30-3,2 $=26.8 \mathrm{t} \mathrm{ha}^{-1}$. Consequently, arenosols had about $30 \mathrm{tC} \mathrm{ha}^{-1}$ less than the French average regardless of the soil type under both forests and vines.

Cultivation in the vineyard plot resulted in a very high carbon stock loss throughout the entire depth: $94 \%$ in the 0-30 cm layer

and $76 \%$ in the $30-60 \mathrm{~cm}$ layer. Although this carbon stock loss phenomenon has already been widely reported (Guillaume et al., 2021; Ramesh et al., 2019), it has generally been found to be around 50\% at the surface during a forest (or grassland) to vineyard transition under all climatic conditions (Carlisle et al., 2006; Eldon and Gershenson, 2015). Moreover, contrary to our findings here, the loss is usually much greater in topsoil than in subsoil layers, ranging from 30 to $63 \%$ on average in the 30-100 cm horizon (Batjes, 2014; Poeplau and Don, 2013). However, if we focus the comparison on arenosols under a

200 Mediterranean climate, losses (in TOC) during a natural vegetation to vine transition can reach $85 \%$ in the $0-20 \mathrm{~cm}$ layer over a 1 year period (Caravaca et al., 2002). The soil carbon loss noted in this study thus resulted in an extremely high carbon loss after more than 150 years of grapevine cultivation, which does not seem to be out of line with observations described in the literature.

This extreme carbon loss throughout the cultivated soil profile could be explained by a combination of four aggravating factors at the Brugassières site: (1) The initial disturbance of the arenosol, due to the forest to vineyard land use change in the 19th century (Caravaca et al., 2002; Tsozué et al., 2020); (2) The absence of vegetation cover (apart from vines) for more than 150 years was probably also an important factor. Carbon inputs were almost nil at the surface (soil kept bare, Fig.1). Deep inputs were limited to the depth of the grapevine root system, while the vine plants were uprooted every 70 years. However, the age of the carbon distribution as a function of depth proposed by Balesdent et al. (2018) shows that almost half of the carbon in a soil is on average younger than 150 years at the soil profile scale. Although this distribution concerns soils under tropical climates, the drastic long-term reduction of carbon inputs to the soil could likely largely explain the carbon stocks observed in the vineyard throughout the soil profile; (3) Deep ploughing $(50 \mathrm{~cm})$, carried out every 70 years at the same time as the grapevine plant uprooting, was probably a third factor favouring carbon loss via accelerated SOC mineralisation; and finally (4) The arenosol texture, characterised by a low proportion of fine particles ( $<20 \mu \mathrm{m}$ fraction, Fig.B2) is also an unfavorable

215 factor for $\mathrm{C}$ storage within the mineral-associated OMs.

\subsection{Intra-layer radiocarbon variability}

Carbon spatial heterogeneity is generally not taken into account in soil studies on carbon dynamics using the ${ }^{14} \mathrm{C}$ proxy (van der Voort et al., 2016). We only found two papers listed in the Shi et al. (2020) database on forest and cultivated soils that addressed intra-layer variability, i.e. Chiti et al. (2016) and van der Voort et al. (2016). These authors showed that the intralayer radiocarbon signature under forests is relatively homogeneous at the soil surface and at depth. This finding is in line with our forest soil results (Fig.2d, Fig.4), where the low intra-layer $\mathrm{F}^{14} \mathrm{C}$ variability (represented by the standard deviation, SD) in the forest soil was noted both in the 5-10 cm layer with a high carbon concentration $\left(\mathrm{SD}_{\mathrm{F} 14 \mathrm{C}}=0.008\right.$; $\mathrm{TOC}_{\text {average }}=42.4 \mathrm{gC} \mathrm{kg}^{-1}$ and $\left.\mathrm{SD}_{\mathrm{TOC}}=9.1 \mathrm{gC} \mathrm{kg}^{-1}\right)$ and in the $40-50 \mathrm{~cm}$ layer with a low carbon concentration $\left(\mathrm{SD}_{\mathrm{F} 14 \mathrm{C}}=0.011 ; \mathrm{TOC}_{\text {average }}=3.4 \mathrm{gC} \mathrm{kg}^{-1}\right.$ and $\mathrm{SD}_{\mathrm{TOC}}=0.1 \mathrm{gC} \mathrm{kg}^{-1}$ ). Low intra-layer variability was also observed in the vineyard soil (Fig.2d, Fig.4), below the ploughing 
https://doi.org/10.5194/soil-2021-115

Preprint. Discussion started: 12 October 2021

(c) Author(s) 2021. CC BY 4.0 License.

(c) (1)

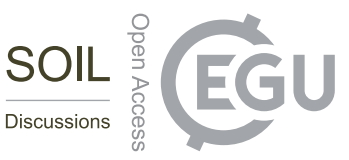

225 depth (50-60 cm layer, $\mathrm{SD}_{\mathrm{F} 14 \mathrm{C}}=0.012 ; \mathrm{TOC}_{\text {average }}=0.9 \mathrm{gC} \mathrm{kg}^{-1}$ and $\left.\mathrm{SD}_{\mathrm{TOC}}=0.1 \mathrm{gC} \mathrm{kg}^{-1}\right)$. Thus, in a horizon undisturbed by agricultural cultivation, ${ }^{14} \mathrm{C}$ showed little intra-layer variability on a metric scale, even when measurements were carried out on samples with a very low TOC (Fig.E3).

In cultivated systems, to our knowledge, no studies have reported measurement of intra-layer ${ }^{14} \mathrm{C}$ variability. Our findings therefore cannot be compared with those of previous studies. In comparison to undisturbed horizons, much higher intra-layer 230 variability was observed at 5-10 $\mathrm{cm}$ depth $\left(\mathrm{SD}_{\mathrm{F} 14 \mathrm{C}}=0.029\right)$ and within the $40-50 \mathrm{~cm}$ ploughing depth $\left(\mathrm{SD}_{\mathrm{F} 14 \mathrm{C}}=0.058\right)$, with both layers being characterized by low total carbon (over 5-10 cm, TOC $=0.79 \mathrm{gC} \mathrm{kg}^{-1}$ with SD=0.26 gC kg-1 ; over $40-50 \mathrm{~cm}$, $\mathrm{TOC}=1.03 \mathrm{gC} \mathrm{kg}^{-1}$ with $\mathrm{SD}=0.42 \mathrm{gC} \mathrm{kg}^{-1}$ ). Furthermore, the $\mathrm{F}^{14} \mathrm{C}$ measurements at $40-50 \mathrm{~cm}$ depth in the $\mathrm{B}$ profile and in vineyard pit composite soils had a post-bomb value $\left(\mathrm{F}^{14} \mathrm{C}_{\text {mean }}=1.001\right)$, which was higher than that obtained in the forest soil $\left(\mathrm{F}^{14} \mathrm{C}_{\text {mean }}=0.990\right)$. At $40-50 \mathrm{~cm}$ depth, and only for this horizon, $\mathrm{OM}$ in the vineyard was therefore younger than that in the 235 forest soil. This highly suggests that the variability in $\mathrm{F}^{14} \mathrm{C}$ measured between the samples on sides $\mathrm{A}, \mathrm{B}$ and $\mathrm{C}$ was a consequence of multiple ploughing whereby the soil is mixed vertically but also horizontally on a metric scale. 
https://doi.org/10.5194/soil-2021-115

Preprint. Discussion started: 12 October 2021

(c) Author(s) 2021. CC BY 4.0 License.

SOLL EGE

(c) (1)

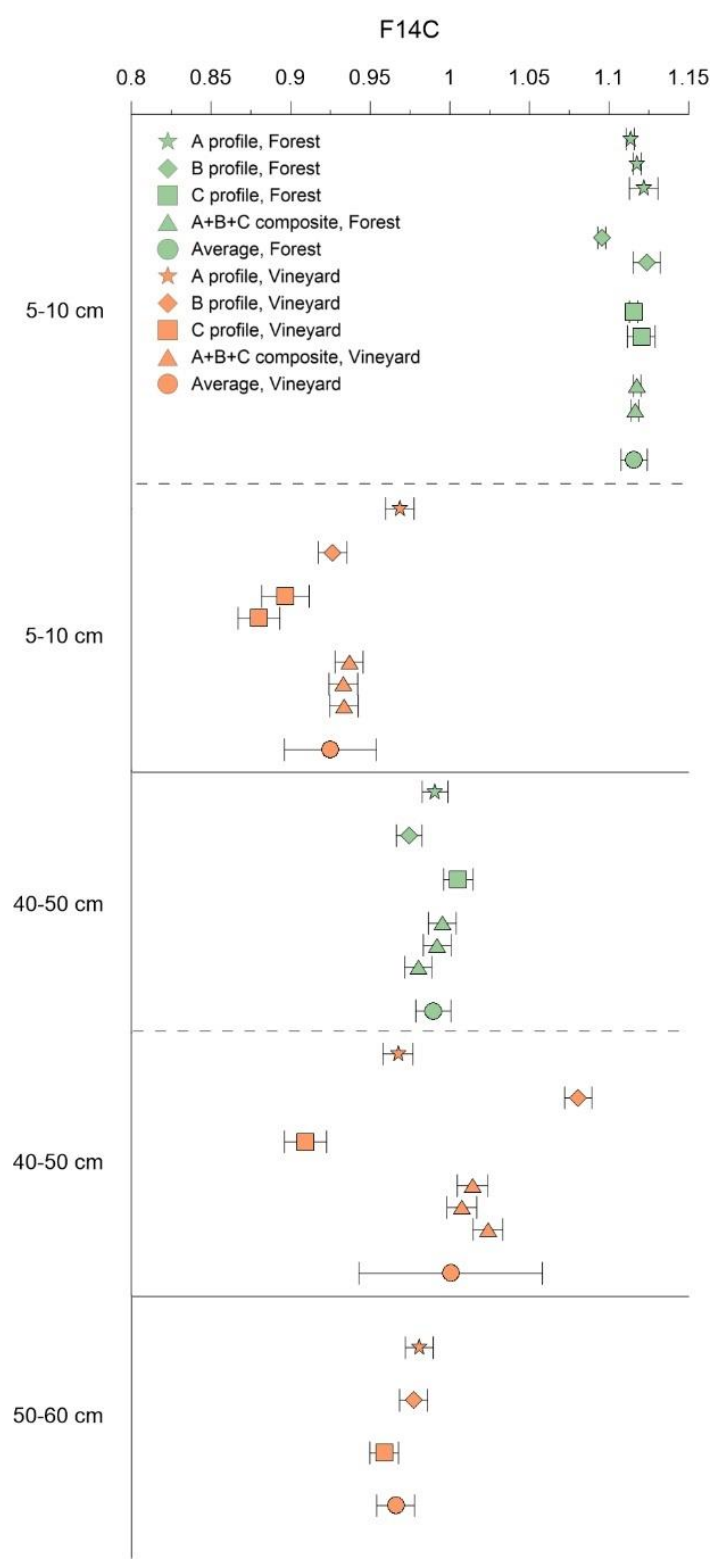

Figure 4: Comparison of intra-layer $\mathrm{F}^{14} \mathrm{C}$ heterogeneity at three depths $(5-10,40-50$ and $50-60 \mathrm{~cm})$ in forest and vineyard soils. $\mathrm{F}^{14} \mathrm{C}$ data were obtained for profiles $A$ (star), B (diamond), C (square), composites A+B+C (triangle) and the average of these data (round), in forest (green) and vineyard (orange) soils. Error bars represent the analytical error for the profiles A, B and C and the standard deviation for the mean.

\subsection{Intra-layer radiocarbon variability}

Based on the meta-analysis of (Shi et al., 2020) and version 1.7.8.2021-01-04 of the ISRaD database (ISRaD, 2020; Lawrence

245 et al., 2020), Figure 5 compares the $\Delta^{14} \mathrm{C}$ of soil profiles reported in 185 papers, under forest and cultivation, at the soil surface $(0-30 \mathrm{~cm})$ and at depth $(30-100 \mathrm{~cm})$. The arenosol studied here had a higher $\Delta{ }^{14} \mathrm{C}$ than the median $\Delta^{14} \mathrm{C}$, all soil types combined, 
in topsoil and even more marked in subsoil layers, e.g. in topsoil, the $\Delta^{14} C_{\text {forest }}=91.5 \pm 166.8$, relative to a median of -9 ( -79 ; 46) from the literature; and $\Delta{ }^{14} \mathrm{C}_{\text {crop }}=-32.7 \pm 183$, relative to a median of $-58(-171 ;-7)$. This was probably due to the lower fine particle content $(<2 \mu \mathrm{m})$ than the overall average in the meta-analysis. Indeed, arenosols have few reactive mineral phases that stabilise OM in the long term, which is in line with the above discussion on stocks. The fact that the OMs were systematically younger than those generally described in the literature could thus be explained by the soil type (i.e. the fine fraction was minimal in the arenosol) and by the long cropland history (> 150 years).

\subsection{Land use impact on $\mathrm{OM}$ borne ${ }^{14} \mathrm{C}$}

In the ploughed horizon, with the exception of the $40-50 \mathrm{~cm}$ layer, $\Delta{ }^{14} \mathrm{C}$ was always more negative in cultivated soils than in forest soils. Cultivation therefore led to carbon aging (by loss of the most recent carbon pool) to $40 \mathrm{~cm}$ depth. This impact of cultivation had already been highlighted in a ploughed horizon by Wang et al. (1999), where the carbon of a cultivated soil in the 0-30 cm layer was older than its equivalent in forest soils. This trend was also revealed in a meta-analysis (Figure 5, cropland-soil $n=34$, forest-soil, $n=151$ papers). The median values confirmed that the carbon age of SOM was older in cultivated soils in both the surface and deep horizons. Cultivation affects the mean carbon turnover by mainly removing carbon from fast-turnover pools and retaining mostly slow-turnover carbon pools (Poeplau and Don, 2013). It is likely that these OM pools are organic compounds associated with the mineral-associated OM (MAOMs) pool (Cotrufo et al., 2019) . Furthermore, the findings in the 40-50 cm horizon, with a younger post-bomb OM than all other horizons in the vineyard profile, showed that the full inversion tillage practiced effectively dragged surface $\mathrm{OM}$ down to $50 \mathrm{~cm}$. Cultivating the deep ploughed arenosol under vines therefore led to (1) loss of the young and poorly stabilised OM pools, and (2) redistribution of the remaining MAOMs throughout the ploughed horizon and, as shown in section 4.3, in a horizontally heterogeneous way.

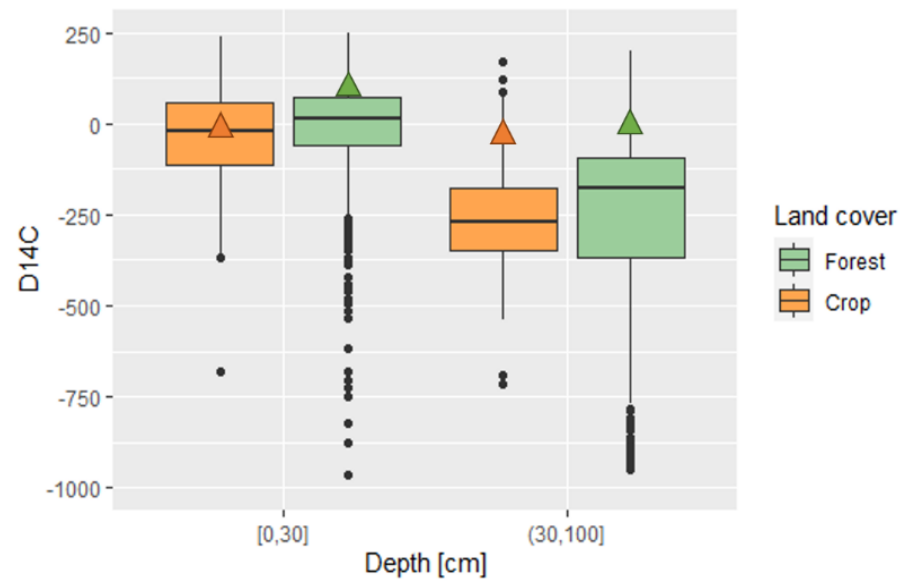

Figure 5: Comparison of the $\Delta^{14} \mathrm{C}$ average at $0-30 \mathrm{~cm}$ and $30-100 \mathrm{~cm}$ depth between this study forest (green triangle), this study crop (orange triangle) and the $\Delta 14 \mathrm{C}$ average from the global ISRaD database (Lawrence et al., 2020; Shi et al., 2020). Black dots represent outliers. Crop-soil $n=34$, forest-soil $n=151$ papers. 
https://doi.org/10.5194/soil-2021-115

Preprint. Discussion started: 12 October 2021

(c) Author(s) 2021. CC BY 4.0 License.

(c) (i)

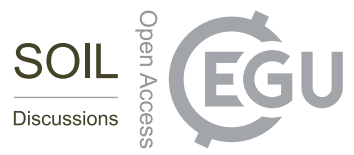

\subsection{Microbial origin of OM in the vineyard}

The C:N ratio of the soil under forest (e.g. $13<\mathrm{C}: \mathrm{N}<16$ on the $0-20 \mathrm{~cm}$ ) was consistent with the average for world soils, (between 9.9<C: $\mathrm{N}<25.8$ (Batjes, 2014)) and with the average for deciduous forest soils (C:N = $13.8 \pm 4.0$ (Cotrufo et al., $2019)$ ). These values mainly corresponded to OM of plant origin. The soil $\mathrm{C}: \mathrm{N}$ ratio under vines $(7<\mathrm{C}: \mathrm{N}<12)$ corresponded to 275 the OM C:N ratio mainly of microbial origin associated with minerals (C: $\mathrm{N}_{\mathrm{MAOM}}=12.6 \pm 4.7$, Cotrufo et al., 2019). The positive correlation obtained between the $\mathrm{C}: \mathrm{N}$ ratio and $\mathrm{F}^{14} \mathrm{C}$ (Fig.6) confirmed that the ancient carbon present in the soil was mainly borne by molecules originating from N-rich microbial metabolism and presumably stabilised within MAOMs (Cotrufo et al., 2019; Kleber et al., 2015). The change in vineyard use associated with conventional practices (absence of inter-row cover crops and deep ploughing) thus seems to only allow the maintenance of this small pool of MAOMs, to the detriment of other less stable OM pools, lost through erosion, leaching or mineralisation.

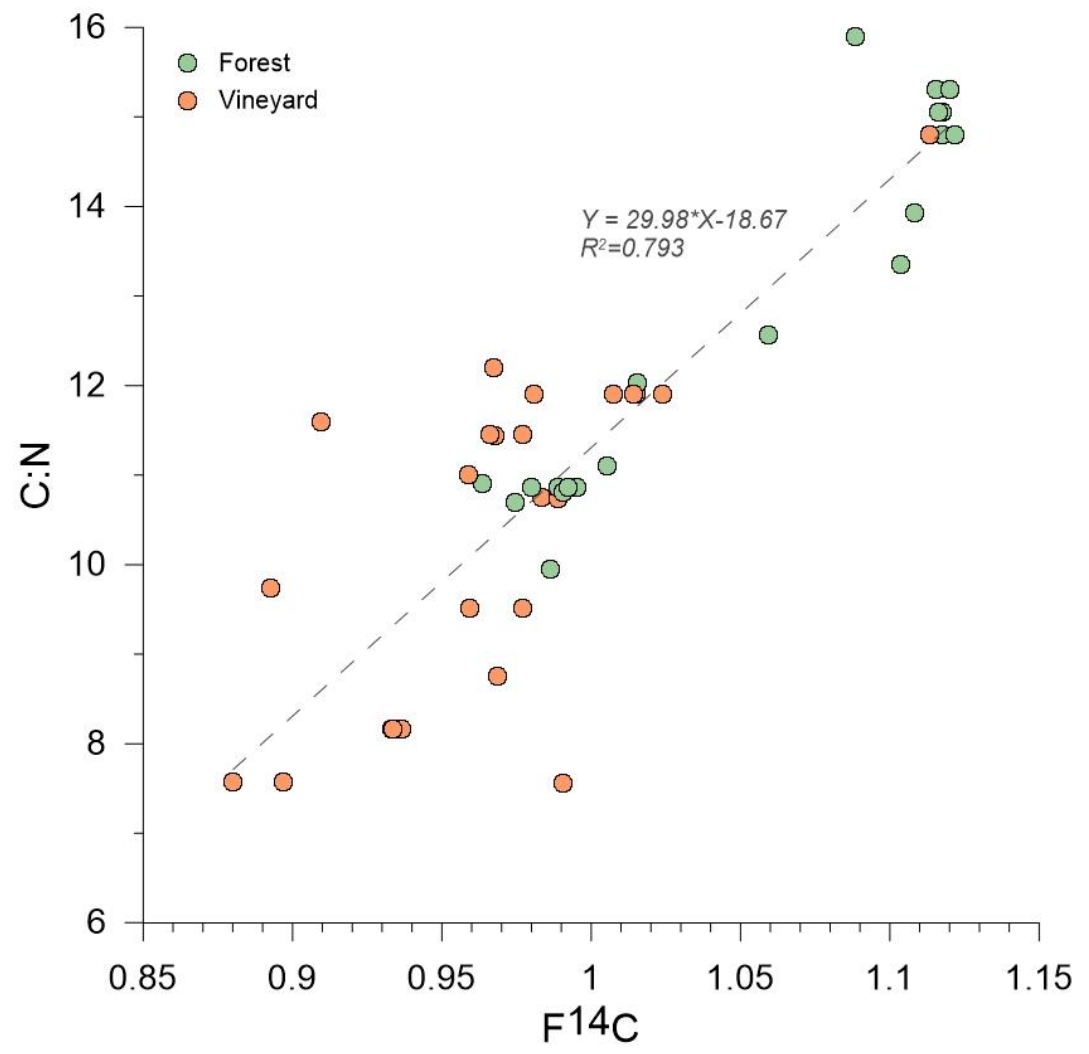

Figure 6: Correlation between the $\mathrm{F}^{14} \mathrm{C}$ and $\mathrm{C}: \mathrm{N}$ ratio. The correlation was calculated on composite samples $\left(\mathrm{F}^{14} \mathrm{C}\right)$ and the average for the 3 profiles $A, B$ and $C(C: N)$, as well as on samples of profiles $A, B$ and $C$ only, from the forest (green) and vineyard (orange). 


\subsection{Are arénosol a good target for the 4:1000 Initiative?}

To restore OM stocks in soils and meet the 4p1000 objectives, the land use pattern may be changed (cropland returned to grassland or forest), or cropland may be maintained by adopting practices that foster $\mathrm{C}$ storage, e.g. establishment of permanent grasslands, application of organic amendments, grassing of vineyards, etc. (Pellerin et al, 2019). Arenosols, whose carbon stocks are very low in cultivated systems (Fig.2c), thus seem to be good candidates for the 4p1000 Initiative because they have a high C storage potential. Storage experiments conducted on arenosols measured an increase of 40.2 to $45.6 \mathrm{t} \mathrm{ha}^{-1}$ and 39.4 to $49.0 \mathrm{t} \mathrm{ha}^{-1}$ of carbon stocks in the 0-30 cm layer in 20 years following, respectively, cropland abandonment $\left(+0.27 \mathrm{t} \mathrm{ha}^{-1} \mathrm{yr}^{-1}\right)$ and a change of grassland management $\left(+0.48 \mathrm{tha}^{-1} \mathrm{yr}^{-1}\right)$ (Kazlauskaite-Jadzevice et al., 2019). In these experiments the annual increase in carbon stock was $+5.9 \%$ and $+9.8 \%$ of the final stock, respectively, i.e. more than 10 -fold higher than the $0.4 \%$ annual increase targeted by the 4 per 1000 Initiative.

295 In the case of the studied arenosols, the potentially achievable reference stock could be considered equal to the forest soil stock. In the 0-30 cm range, the $\mathrm{C}$ storage potential was therefore $48 \mathrm{t} \mathrm{ha}^{-1}$ (Fig.2c). If we consider an annual C stock increase rate equivalet to that obtained by Kazlauskaite-Jadzevice et al. (2019), we could calculate that an arenosol could recover this stock in 14 years under appropriate practices (i.e. $3.4 \mathrm{t} \mathrm{ha}^{-1} \mathrm{yr}^{-1}$ ). If we calculate differently, considering not the same storage proportion as Kazlauskaite-Jadzevice et al. (2019) but the same storage rate (a mean value of $+0.37 \mathrm{tha}^{-1} \mathrm{yr}^{-1}$ ), an arenosol could recover its $\mathrm{C}$ stock in 128 years of storage practice. The reality would probably fall between these two values and the system would probably not respond linearly. The additional $\mathrm{C}$ storage potential in cultivated arenosols is thus high, but these calculations, although very simplistic, show that there is still considerable uncertainty about the time needed to reach maxi mum storage. In any case, although these time scales are still poorly understood, ambitious annual soil carbon storage objectives could clearly be met in arenosols upon the adoption of $\mathrm{C}$ storage practices.

\section{Conclusion}

Land use change from a Mediterranean forest to a vineyard on an arenosol resulted in loss of almost all of the soil's carbon throughout the entire depth of the soil profile: $93.7 \%$ less SOC at the surface and $76.2 \%$ at depth. The few research papers (2) that we found with comparable levels did not report enough detail (e.g. history of the plots) to be able to understand why their reported values corresponded to those found at our Les Brugassières site. The radiocarbon study highlighted the very high vertical homogeneity (as a function of depth) and horizontal heterogeneity (intra-layer) of the carbon distribution, induced by the deep ploughing practice. The carbon remaining in the $>50 \mathrm{~cm}$ soil layer was old, stabilized microbial carbon that was mixed with younger carbon at depth. The study of ${ }^{14} \mathrm{C}$ data and the $\mathrm{C}: \mathrm{N}$ ratio revealed a link between the degree of $\mathrm{OM}$ biotransformation by the microbial compartment and its age, i.e. $\mathrm{F}^{14} \mathrm{C}$ (old and stabilized carbon) decreased with the C:N ratio. Finally, arenosols are soils for which the adoption of $\mathrm{C}$ stocking practices can meet ambitious annual soil carbon storage objectives. The findings of this study thus generated fresh knowledge on the carbon dynamics of arenosols following a land use change, with a view to application of the 4p1000 Initiative. 


\section{Appendix A}

$\mathrm{F}^{14} \mathrm{C}$ represents the raw radiocarbon activity value and to have access to the age of organic material formed after the 1960 bomb peak. This unit takes isotope fractionation into account and, most importantly, does not depend on the year of measurement (Reimer et al., 2004) Eq.(A1) :

$F^{14} \mathrm{C}=\frac{A_{\mathrm{SN}}}{A_{O N}}$

AON is the normalized oxalic acid activity, equivalent to the atmospheric activity in 1950, before the bomb peak. ASN represents the sample activity, normalised by the isotopic fractionation that occurs via plants during photosynthesis. The correction is a reference for $13 \mathrm{C}$ fractionation with a value of $-25 \%$. As is the sample activity at the dating time Eq.(A2, A3) :

$A_{S N}=A_{S}\left(1-2 *\left(\frac{25+\partial^{13} C}{1000}\right)\right)$

$A_{S}=\frac{{ }^{14} \text { C sample atoms }}{{ }^{14} \text { C sample atoms }}$

However, many authors use $\Delta 14 \mathrm{C}$ to express $14 \mathrm{C}$, which represents the deviation of the sample $14 \mathrm{C}$ content from the bomb peak but it depends on the year it was measured, regardless of the age of the sample (Reimer et al., 2004; Stuiver and Polach, 1977). The data expressed in $\Delta 14 \mathrm{C}$ is shown Fig.E2 to facilitate comparison with the literature findings, Eq.(A4):

$\Delta^{14} C=\left(F^{14} C / e(((\right.$ years -1950$) /(5730 / \ln 2))-1) * 1000$,

From the radiocarbon data, it is possible to access a relative age, expressed in years before present (BP). The starting date of the age scale is 1 January 1950, which was before the bombs peak, and corresponds to the first publications with radiocarbon dates. The BP age takes the radiocarbon decay equation into account and was calculated according to the Libby half-life of 3355568 years (Libby et al., 1949), Eq.(A5):

Age $B P=-5568 * \frac{\ln \left(F^{14} C\right)}{\ln 2}$, 


\section{Appendix B}

19th century

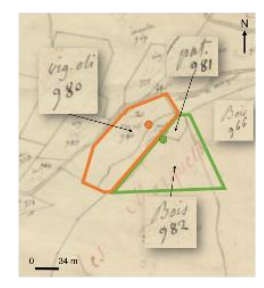

20th century

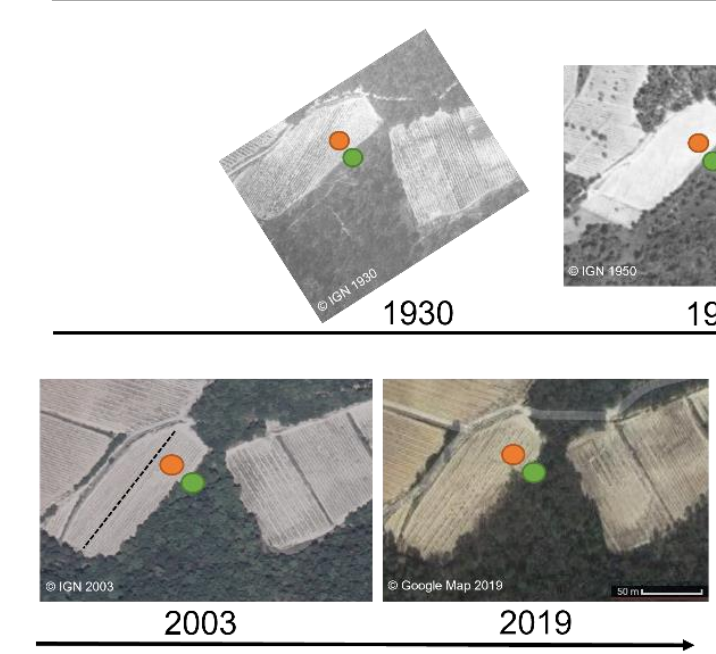

\section{1 th} century

Figure B1 History of land use at the Les Brugassières site from the 19th century to present day, through the study of old maps and aerial photos. The boundaries of the forest (green) and vineyard (orange) plots were shown on the Napoleonic land register (1808-1848, https://archives.var.fr). All aerial photos from the 20th century to present day, except 2019, were from the IGN Remonter le temps website (https://remonterletemps.ign.fr/, IGN - National Photo Library - [1930, 1950, 1960, 1998, 2003]). The 2019 photo was from (C) Google Map website (https://maps.google.fr). The pit locations are indicated by orange and green circles. 


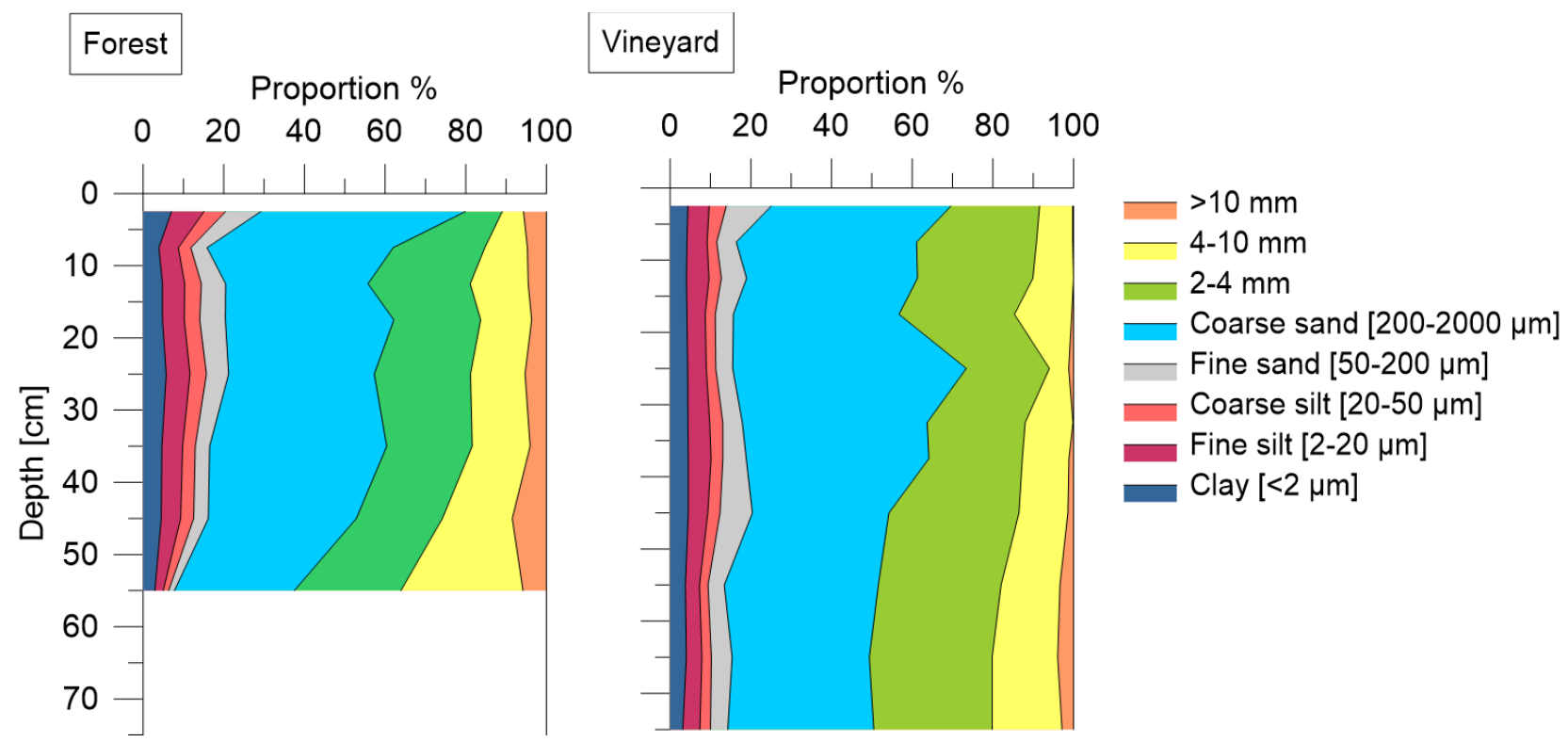

Figure B2 Granulometry comparison between the pits under the forest and under the vineyard, as a function of depth. The eight grain size fractions, clay $<2 \mu \mathrm{m}$ (dark blue), fine silt 2-20 $\mu \mathrm{m}$ (burgundy), coarse silt 20-50 $\mu \mathrm{m}$ (pink), fine sand 50-200 $\mu \mathrm{m}$ (grey), coarse sand 200-2000 $\mu \mathrm{m}$ (sky blue), 2-4 mm (green), 4-10 mm (yellow) and >10 mm (orange), are expressed in $\%$ of the mineral phase. The particle size profiles in the forest and vineyard soils showed about $50 \%$ coarse sand and did not vary significantly with depth. There was no significant difference in soil granulometry between the forest plot and the vineyard plot. 


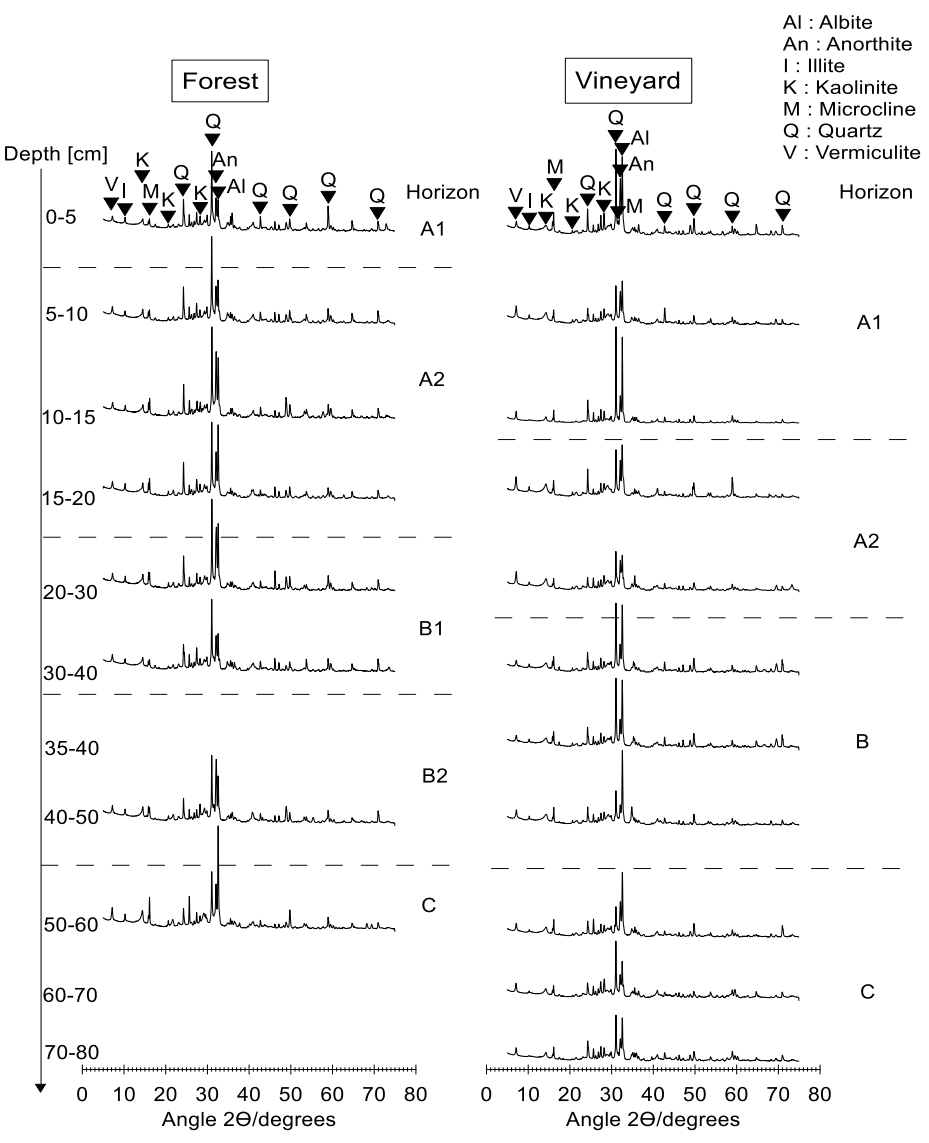

360 Figure B3 Forest/vineyard comparison of X-ray diffractograms as a function of soil depth. The rhombs indicate the peak considered and the letters above are the corresponding minerals. The mineralogy was determined by X-ray diffraction on powder samples, deposited on a silicon plate, and measured by a PANalytical X'pert PRO diffractometer, with a cobalt radiation source. The range of $2 \theta$ was between $5^{\circ}$ and $75^{\circ}$, with a step size of $0.033^{\circ}$ and a measurement time of $5 \mathrm{~h} 10 \mathrm{~min}$ per sample. The the forest and cultivated soil mineralogy is characteristic of a granitic bedrock with quartz, feldspar and secondary minerals (illite and vermiculite), throughout the entire profile. The mineralogy was equivalent in both soils. 
https://doi.org/10.5194/soil-2021-115

Preprint. Discussion started: 12 October 2021

(c) Author(s) 2021. CC BY 4.0 License.

SOIL

Discussions (c) (1)

\section{Appendix C}

Table C1 Table of bulk density $\left[\mathrm{g} \mathrm{cm}^{-3}\right]$, carbon content $\left[\mathrm{gC} \mathrm{kg}^{-1}\right], \mathrm{C}: \mathrm{N}$ ratio as a function of plant cover and depth. A,B,C are the pit profiles, BD is the bulk density, \pm is the analytical error, $\mathrm{X}$ is the mean of the 3 profiles $\mathrm{A}, \mathrm{B}$ and $\mathrm{C}$ and $\mathrm{SD}$ is the standard deviation.

\begin{tabular}{|c|c|c|c|c|c|c|c|c|c|c|c|c|c|c|c|c|c|}
\hline & \multirow[b]{2}{*}{$\begin{array}{c}\text { Depth } \\
{[\mathrm{cm}]}\end{array}$} & \multicolumn{5}{|c|}{$\begin{array}{c}\text { BD } \\
\mathrm{g} \mathrm{cm}^{-3}\end{array}$} & \multicolumn{5}{|c|}{$\begin{array}{c}\text { TOC } \\
\mathrm{gC} \mathrm{kg}^{-1}\end{array}$} & \multicolumn{6}{|c|}{$\mathrm{C}: \mathrm{N}$} \\
\hline & & A & B & C & $x$ & SD & A & B & C & $\mathbf{x}$ & SD & A & B & & C & $\mathbf{x}$ & SD \\
\hline \multirow[t]{10}{*}{ Vineyard } & $0-5$ & 1.55 & 1.14 & 1.17 & 1.29 & 0.23 & $2.17 \pm 0.27$ & $2.38 \pm 0.27$ & $0.93 \pm 0.23$ & 1.83 & 0.78 & $7.00 \pm 1.57$ & $10.80 \pm 2.62$ & 4.89 & \pm 1.90 & 7.56 & 3.00 \\
\hline & $5-10$ & 1.59 & 0.84 & 1.09 & 1.17 & 0.38 & $1.05 \pm 0.23$ & $0.79 \pm 0.22$ & $0.53 \pm 0.22$ & 0.79 & 0.26 & $8.75 \pm 3.71$ & & 7.57 & \pm 5.53 & 8.16 & 0.83 \\
\hline & $10-15$ & 1.60 & 0.89 & 0.94 & 1.14 & 0.40 & $1.21 \pm 0.24$ & $0.61 \pm 0.22$ & $1.03 \pm 0.23$ & 0.95 & 0.31 & $10.10 \pm 4.02$ & & 11.40 & \pm 5.53 & 10.75 & 0.92 \\
\hline & $15-20$ & 1.60 & 0.79 & 0.96 & 1.12 & 0.43 & $0.93 \pm 0.23$ & $0.73 \pm 0.22$ & $1.30 \pm 0.24$ & 0.99 & 0.29 & $10.30 \pm 5.21$ & $12.20 \pm 8.20$ & 11.80 & \pm 4.76 & 11.43 & 1.00 \\
\hline & $20-30$ & 0.81 & 1.08 & 1.03 & 0.98 & 0.14 & $0.79 \pm 0.22$ & $0.67 \pm 0.22$ & $1.28 \pm 0.24$ & 0.91 & 0.32 & $9.88 \pm 5.63$ & & 9.14 & \pm 3.35 & 9.51 & 0.52 \\
\hline & $30-40$ & 1.02 & 0.90 & 0.86 & 0.93 & 0.09 & $0.74 \pm 0.22$ & $1.35 \pm 0.24$ & $1.01 \pm 0.23$ & 1.03 & 0.30 & $10.60 \pm 6.59$ & $11.50 \pm 4.35$ & 10.10 & \pm 4.70 & 10.73 & 0.71 \\
\hline & $40-50$ & 1.00 & 0.82 & 0.85 & 0.89 & 0.10 & $1.10 \pm 0.23$ & $1.42 \pm 0.24$ & $0.58 \pm 0.22$ & 1.03 & 0.42 & $12.20 \pm 5.76$ & & 11.60 & \pm 9.42 & 11.90 & 0.42 \\
\hline & $50-60$ & 1.06 & 0.75 & 1.05 & 0.95 & 0.18 & $0.83 \pm 0.23$ & $0.94 \pm 0.24$ & $0.88 \pm 0.23$ & 0.88 & 0.05 & $11.90 \pm 7.04$ & & 11.00 & \pm 5.99 & 11.45 & 0.64 \\
\hline & $60-70$ & 0.92 & 0.78 & 0.98 & 0.90 & 0.10 & $0.53 \pm 0.22$ & $0.69 \pm 0.23$ & $0.92 \pm 0.23$ & 0.71 & 0.20 & $8.83 \pm 6.87$ & & 10.20 & \pm 5.18 & 9.52 & 0.97 \\
\hline & $70-80$ & & & & & & $0.42 \pm 0.21$ & $0.34 \pm 0.22$ & $0.87 \pm 0.23$ & 0.54 & 0.29 & $7.00 \pm 6.14$ & $11.30 \pm 14.98$ & 10.90 & \pm 5.95 & 9.73 & 2.38 \\
\hline \multirow[t]{9}{*}{ Forest } & $0-5$ & 1.21 & 1.42 & & 1.32 & 0.15 & $44.00 \pm 1.56$ & $32.60 \pm 1.21$ & $50.7 \pm 1.77$ & 42.43 & 9.15 & $16.10 \pm 1.27$ & $2.12 \pm 1.27$ & 3.13 & \pm 1.25 & 7.12 & 7.80 \\
\hline & $5-10$ & 1.46 & 1.65 & & 1.56 & 0.13 & $23.80 \pm 0.94$ & $17.50 \pm 0.74$ & $28.4 \pm 1.08$ & 23.23 & 5.47 & $14.80 \pm 1.30$ & $0.00 \pm 0.00$ & 1.86 & \pm 1.29 & 5.55 & 8.06 \\
\hline & $10-15$ & 1.49 & 1.73 & & 1.61 & 0.17 & $12.50 \pm 0.59$ & $12.50 \pm 0.59$ & $15.2 \pm 0.67$ & 13.40 & 1.56 & $13.50 \pm 1.42$ & $0.88 \pm 1.50$ & 1.08 & \pm 1.39 & 5.15 & 7.23 \\
\hline & $15-20$ & 1.48 & 1.40 & & 1.44 & 0.06 & $7.72 \pm 0.44$ & $9.29 \pm 0.49$ & $10.5 \pm 0.53$ & 9.17 & 1.39 & $13.30 \pm 1.70$ & $0.00 \pm 0.00$ & 0.78 & \pm 1.50 & 4.69 & 7.46 \\
\hline & $20-30$ & 1.65 & 1.62 & & 1.63 & 0.02 & $5.18 \pm 0.36$ & $5.94 \pm 0.38$ & $7.87 \pm 0.44$ & 6.33 & 1.39 & $12.00 \pm 1.83$ & $0.48 \pm 1.76$ & 0.59 & \pm 1.68 & 4.36 & 6.62 \\
\hline & $30-40$ & 1.74 & 1.67 & & 1.70 & 0.05 & $4.34 \pm 0.33$ & $4.16 \pm 0.33$ & $4.98 \pm 0.35$ & 4.49 & 0.43 & $11.70 \pm 1.96$ & $0.36 \pm 1.97$ & 0.39 & \pm 2.02 & 4.15 & 6.54 \\
\hline & $40-50$ & 1.72 & 1.55 & & 1.64 & 0.12 & $3.44 \pm 0.31$ & $3.41 \pm 0.31$ & $3.32 \pm 0.30$ & 3.39 & 0.06 & $10.80 \pm 2.02$ & $0.32 \pm 2.00$ & 0.30 & \pm 2.15 & 3.81 & 6.06 \\
\hline & $50-60$ & 1.70 & 1.58 & & 1.64 & 0.09 & $2.70 \pm 0.28$ & $1.89 \pm 0.26$ & $2.25 \pm 0.27$ & 2.28 & 0.41 & $10.40 \pm 2.26$ & $0.18 \pm 2.98$ & 0.19 & \pm 3.09 & 3.59 & 5.90 \\
\hline & $60-70$ & 1.74 & 1.68 & & 1.71 & 0.04 & $2.09 \pm 0.26$ & & & 2.09 & & $9.95 \pm 2.57$ & & & & 9.95 & \\
\hline
\end{tabular}

Table C2 $\mathrm{F}^{14} \mathrm{C}$ per composite sample $(\mathrm{A}+\mathrm{B}+\mathrm{C})$ or per profile $(\mathrm{A}, \mathrm{B}$ and $\mathrm{C})$ according to soil depth, the numbers 1,2 or 3 indicate the repetitions, \pm is the analytical error.

\begin{tabular}{|c|c|c|c|c|c|c|c|c|c|c|c|c|c|c|c|c|c|c|c|c|c|}
\hline & \multirow[b]{3}{*}{$\begin{array}{l}\text { Depth } \\
{[\mathrm{cm}]}\end{array}$} & \multicolumn{6}{|c|}{$A+B+C$} & \multicolumn{6}{|c|}{ A } & \multicolumn{4}{|c|}{ B } & \multicolumn{4}{|c|}{ c } \\
\hline & & & 1 & & 2 & & 3 & & 1 & & 2 & & 3 & & 1 & & 2 & & 1 & & 2 \\
\hline & & $\begin{array}{c}C \\
{[\mu \mathrm{g}]}\end{array}$ & $\mathrm{F}^{14} \mathrm{C}$ & $\begin{array}{c}C \\
{[\mu \mathrm{g}]}\end{array}$ & $F^{14} C$ & $\begin{array}{c}\mathrm{C} \\
{[\mu \mathrm{g}]}\end{array}$ & $\mathrm{F}^{14} \mathrm{C}$ & $\begin{array}{c}\mathrm{C} \\
{[\mu \mathrm{g}]}\end{array}$ & $F^{14} C$ & $\begin{array}{c}C \\
{[\mu \mathrm{g}]}\end{array}$ & $\mathrm{F}^{14} \mathrm{C}$ & $\begin{array}{r}C \\
{[\mu \mathrm{g}]}\end{array}$ & $F^{14} C$ & $\begin{array}{c}C \\
{[\mu \mathrm{g}]}\end{array}$ & $\mathrm{F}^{14} \mathrm{C}$ & $\begin{array}{c}\mathrm{C} \\
{[\mu \mathrm{g}]}\end{array}$ & $\mathrm{F}^{14} \mathrm{C}$ & $\begin{array}{c}\mathrm{C} \\
{[\mu \mathrm{g}]}\end{array}$ & $\mathrm{F}^{14} \mathrm{C}$ & $\begin{array}{c}C \\
{[\mu \mathrm{g}]}\end{array}$ & $\mathrm{F}^{14} \mathrm{C}$ \\
\hline \multirow[t]{10}{*}{ Vineyard } & $0-5$ & 71.3 & $0.990 \pm 0.009$ & & & & & & & & & & & & & & & & & & \\
\hline & $5-10$ & 59.3 & $0.937 \pm 0.009$ & 54.8 & $0.933 \pm 0.009$ & 54.0 & $0.933 \pm 0.009$ & 54.8 & $0.969 \pm 0.009$ & & & & & 54.8 & $0.926 \pm 0.009$ & & & 26.3 & $0.897 \pm 0.015$ & 27.8 & $0.880 \pm 0.013$ \\
\hline & $10-15$ & 54.0 & $0.984 \pm 0.009$ & & & & & & & & & & & & & & & & & & \\
\hline & $15-20$ & 45.0 & $0.968 \pm 0.010$ & & & & & & & & & & & & & & & & & & \\
\hline & $20-30$ & 50.3 & $0.977 \pm 0.010$ & & & & & & & & & & & & & & & & & & \\
\hline & $30-40$ & 55.5 & $0.989 \pm 0.009$ & & & & & & & & & & & & & & & & & & \\
\hline & $40-50$ & 50.3 & $1.014 \pm 0.010$ & 53.3 & $1.008 \pm 0.009$ & 53.3 & $1.024 \pm 0.009$ & 48.0 & $0.967 \pm 0.009$ & & & & & 86.3 & $1.081 \pm 0.009$ & & & 27.0 & $0.909 \pm 0.013$ & & \\
\hline & $50-60$ & 51.4 & $0.966 \pm 0.009$ & & & & & 40.0 & $0.981 \pm 0.009$ & & & & & 36.0 & $0.977 \pm 0.009$ & & & 34.0 & $0.959 \pm 0.009$ & & \\
\hline & $60-70$ & 25.7 & $0.959 \pm 0.014$ & & & & & & & & & & & & & & & & & & \\
\hline & $70-80$ & 24.0 & $0.893 \pm 0.014$ & & & & & & & & & & & & & & & & & & \\
\hline \multirow[t]{9}{*}{ Forest } & $0-5$ & $\begin{array}{c}998.0 \\
1\end{array}$ & $1.089 \pm 0.003$ & & & & & & & & & & & & & & & & & & \\
\hline & $5-10$ & 000.0 & $1.118 \pm 0.002$ & 988.0 & $1.116 \pm 0.002$ & & & 1000.0 & $1.113 \pm 0.003$ & 987.0 & $1.118 \pm 0.003$ & B 123.8 & $1.122 \pm 0.009$ & 998.0 & $1.095 \pm 0.002$ & 108.0 & $1.124 \pm 0.009$ & 997.0 & $1.115 \pm 0.003$ & 93.8 & $1.120 \pm 0.009$ \\
\hline & $10-15$ & 997.0 & $1.108 \pm 0.002$ & & & & & & & & & & & & & & & & & & \\
\hline & $15-20$ & 996.0 & $1.104 \pm 0.002$ & & & & & & & & & & & & & & & & & & \\
\hline & $20-30$ & 983.0 & $1.059 \pm 0.002$ & & & & & & & & & & & & & & & & & & \\
\hline & $30-40$ & 986.0 & $1.015 \pm 0.002$ & & & & & & & & & & & & & & & & & & \\
\hline & $40-50$ & 86.6 & $0.995 \pm 0.009$ & 86.57 & $0.980 \pm 0.009$ & 86.57 & $0.980 \pm 0.009$ & 90.9 & $0.991 \pm 0.008$ & & & & & 90.9 & $0.974 \pm 0.008$ & & & 86.6 & $1.005 \pm 0.009$ & & \\
\hline & $50-60$ & 91.7 & $0.964 \pm 0.008$ & & & & & & & & & & & & & & & & & & \\
\hline & $60-70$ & 89.1 & $0.986 \pm 0.008$ & & & & & & & & & & & & & & & & & & \\
\hline
\end{tabular}


https://doi.org/10.5194/soil-2021-115

Preprint. Discussion started: 12 October 2021

(c) Author(s) 2021. CC BY 4.0 License.

SOLL E̊ EGU

\section{Appendix D}

380 Table D1 listing papers used in this study, with land use type for each soil and associated TOC as a function of depth. These papers all deal with arenosols, or at least sandy soils, in Mediterranean climates according to the Köppen-Geiger criteria. They were found by accessing the ISRaD database or the Web of Science with the keywords " ${ }^{14} \mathrm{C}$ arenosol heterogeneity".

\begin{tabular}{|c|c|c|c|c|c|c|c|c|c|c|}
\hline Paper & $\begin{array}{l}\text { Publication } \\
\text { year }\end{array}$ & Country & DOI & Soil type/major texture & \multicolumn{2}{|c|}{ Climat Land use } & $\begin{array}{c}\text { Plot Age } \\
\text { years }\end{array}$ & $\begin{array}{c}\text { Depth } \\
\mathbf{c m}\end{array}$ & $\begin{array}{r}\text { TOC } \\
\mathrm{g} \mathrm{kg}^{-1} \\
\end{array}$ & $\begin{array}{c}E T \\
\mathrm{~g} \mathrm{~kg}^{-1} \\
\end{array}$ \\
\hline Andreetta et al. & 2013 & Italy & $10.1007 / \mathrm{s} 10533-011-9693-9$ & Haplic Arenosol & csa & Holm oak forest & 50 & $0-5$ & 104.7 & na \\
\hline Andreetta et al. & 2013 & Italy & $10.1007 / \mathrm{s} 10533-011-9693-9$ & Haplic Arenosol & csa & Holm oak forest & 50 & $5-11$ & 9.3 & na \\
\hline Andreetta et al. & 2013 & Italy & $10.1007 / \mathrm{s} 10533-011-9693-9$ & Haplic Arenosol & csa & Holm oak forest & 50 & $11-30$ & 14.2 & na \\
\hline Andreetta et al. & 2013 & Italy & $10.1007 / \mathrm{s} 10533-011-9693-9$ & Haplic Arenosol & csa & Holm oak forest & 50 & $30-55$ & 6.1 & na \\
\hline Andreetta et al. & 2013 & Italy & $10.1007 / \mathrm{s} 10533-011-9693-9$ & Haplic Arenosol & csa & Holm oak forest & 50 & $55-75$ & 2.1 & na \\
\hline Andreetta et al. & 2013 & Italy & $10.1007 / \mathrm{s} 10533-011-9693-9$ & Haplic Arenosol & csa & Holm oak forest & 50 & $75-120$ & 1.4 & na \\
\hline Caravaca et al. & 2002 & Spain & $10.1016 / \mathrm{S} 0167-1987(02) 00080-6$ & Calcaric Arenosol & csa & Spontaneous grass cover & na & $0-20$ & 21.3 & na \\
\hline Caravaca et al. & 2002 & Spain & $10.1016 / \mathrm{S} 0167-1987(02) 00080-6$ & Calcaric Arenosol & $\operatorname{csa}$ & vineyard & na & $0-20$ & 3.2 & na \\
\hline Conradie & 2001 & South Africa & https://doi.org/10.21548/22-2-2192 & Sandy soil & scb & vineyard & na & $20-40$ & 1.7 & na \\
\hline Conradie & 2001 & South Africa & https://doi.org/10.21548/22-2-2192 & Sandy soil & $\mathrm{scb}$ & vineyard & na & $40-60$ & 1.6 & na \\
\hline Fierro et al. & 2007 & Italy & 10.1071MF06114 & Calcaric Arenosol & csa & forest & na & $0-5$ & 47 & 7 \\
\hline Fierro et al. & 2007 & Italy & 10.1071 NF061 14 & Calcaric Arenosol & csa & forest & na & $0-5$ & 48 & 8 \\
\hline Fierro et al. & 2007 & Italy & 10.1071MF061 14 & Calcaric Arenosol & csa & forest & na & $0-5$ & 45 & 15 \\
\hline Fierro et al. & 2007 & Italy & 10.1071 NF061 14 & Calcaric Arenosol & csa & forest & na & $0-5$ & 50 & 21 \\
\hline Fierro et al. & 2007 & Italy & 10.1071/NF061 14 & Calcaric Arenosol & csa & forest & na & $0-5$ & 54 & 21 \\
\hline Fierro et al. & 2007 & Italy & 10.1071 WF06114 & Calcaric Arenosol & csa & forest & na & $0-5$ & 48.8 & 14.4 \\
\hline Fourie et al. & 2005 & South Africa & https://doi.org/10.21548/26-2-2129 & Sandy soil & csb & vineyard & na & $0-30$ & 1.3 & na \\
\hline Fourie et al. & 2005 & South Africa & https://doi.org/10.21548/26-2-2129 & Sandy soil & $c s b$ & vineyard & na & $30-60$ & 1.0 & na \\
\hline López-Piñeiro et al. & 2013 & Spain & http://dx.doi.org/10.1016/j.still.2012.09.007 & Loamy sand soil & csa & vineyard & na & $0-10$ & 1.73 & na \\
\hline Okur et al. & 2009 & Turkey & $10.3906 /$ tar-0806-23 & Sandy loamy soil & csa & vineyard & na & $0-20$ & 7.8 & na \\
\hline Pinzari et al. & 1999 & Italy & $10.1016 / \mathrm{S} 0167-7012(99) 00007-\mathrm{X}$ & Sandy soil & csa & Natural oak foret & 100 & $0-20$ & 16 & 1.62 \\
\hline Pinzari et al. & 1999 & Italy & 10.1016/S0167-7012(99)00007-X & Sandy soil & csa & Natural oak foret & 100 & $20-40$ & 5.6 & 0.33 \\
\hline Pinzari et al. & 1999 & Italy & $10.1016 / \mathrm{S} 0167-7012(99) 00007-\mathrm{X}$ & Sandy soil & csa & maquis & na & $0-20$ & 31 & 2.45 \\
\hline Pinzari et al. & 1999 & Italy & $10.1016 / \mathrm{S} 0167-7012(99) 00007-\mathrm{X}$ & Sandy soil & csa & maquis & na & $20-40$ & 7.7 & 0.45 \\
\hline Pinzari et al. & 1999 & Italy & 10.1016/S0167-7012(99)00007-X & Sandy soil & csa & pine forest plantation & 60 & $0-20$ & 20.1 & 2.56 \\
\hline Pinzari et al. & 1999 & Italy & $10.1016 / \mathrm{S} 0167-7012(99) 00007-\mathrm{X}$ & Sandy soil & csa & pine forest plantation & 60 & $20-40$ & 6.1 & 0.25 \\
\hline Pinzari et al. & 1999 & Italy & $10.1016 / \mathrm{S} 0167-7012(99) 00007-\mathrm{X}$ & Sandy soil & csa & natural mixed forest & na & $0-20$ & 22.7 & 2.06 \\
\hline Pinzari et al. & 1999 & Italy & $10.1016 / \mathrm{S} 0167-7012(99) 00007-\mathrm{X}$ & Sandy soil & csa & natural mixed forest & na & $20-40$ & 19 & 0.41 \\
\hline Vittori Antisari et al. & 2016 & Italy & $10.1007 / \mathrm{s} 12665-016-5581-\mathrm{x}$ & Haplic arenosol & csa & Holm forest & na & $0-3$ & 72.0 & 5.6 \\
\hline Vittori Antisari et al. & 2016 & Italy & $10.1007 / \mathrm{s} 12665-016-5581-\mathrm{x}$ & Haplic arenosol & csa & Holm forest & na & $3-7$ & 49.3 & 2.4 \\
\hline Vittori Antisari et al. & 2016 & Italy & $10.1007 / \mathrm{s} 12665-016-5581-\mathrm{x}$ & Haplic arenosol & $\operatorname{csa}$ & Holm forest & na & $7-12$ & 10.5 & 0.5 \\
\hline Vittori Antisari et al. & 2016 & Italy & $10.1007 / s 12665-016-5581-x$ & Haplic arenosol & $\operatorname{csa}$ & Holm forest & na & $12-50$ & 1.8 & 0.3 \\
\hline Vittori Antisari et al. & 2016 & Italy & $10.1007 / \mathrm{s} 12665-016-5581-\mathrm{x}$ & Haplic arenosol & $\operatorname{csa}$ & Pine forest & na & $0-3$ & 42.7 & 1.5 \\
\hline Vittori Antisari et al. & 2016 & Italy & $10.1007 / s 12665-016-5581-x$ & Haplic arenosol & csa & Pine forest & na & $3-11$ & 10.5 & 1.3 \\
\hline Vittori Antisari et al. & 2016 & Italy & $10.1007 / s 12665-016-5581-x$ & Haplic arenosol & csa & Pine forest & na & $11-25$ & 1.9 & 0.4 \\
\hline Vittori Antisari et al. & 2016 & Italy & $10.1007 / s 12665-016-5581-x$ & Haplic arenosol & csa & Pine forest & na & $25-50$ & 1.2 & 0.3 \\
\hline Vittori Antisari et al. & 2016 & Italy & $10.1007 / s 12665-016-5581-x$ & Brunic arenosol & csa & Hygro forest (oak) & 245 & $0-3$ & 49.7 & 3.1 \\
\hline Vittori Antisari et al. & 2016 & Italy & $10.1007 / \mathrm{s} 12665-016-5581-\mathrm{x}$ & Brunic arenosol & csa & Hygro forest & 245 & $3-6$ & 19.6 & 1.2 \\
\hline Vittori Antisari et al. & 2016 & Italy & $10.1007 / \mathrm{s} 12665-016-5581-\mathrm{x}$ & Brunic arenosol & csa & Hygro forest & 245 & $6-12$ & 9.6 & 1.8 \\
\hline Vittori Antisari et al. & 2016 & Italy & $10.1007 / \mathrm{s} 12665-016-5581-\mathrm{x}$ & Brunic arenosol & csa & Hygro forest & 245 & $12-19$ & 2.1 & 0.3 \\
\hline
\end{tabular}


https://doi.org/10.5194/soil-2021-115

Preprint. Discussion started: 12 October 2021

(c) Author(s) 2021. CC BY 4.0 License.

Son. EG

385 Table D2 Köppen-Geiger criteria. The Köppen-Geiger Mediterranean climate classes including the defining criteria, adapted from (Beck et al., 2018): MAT = mean annual air temperature $\left({ }^{\circ} \mathrm{C}\right)$; Tcold $=$ air temperature of the coldest month $\left({ }^{\circ} \mathrm{C}\right)$; Thot $=$ air temperature of the warmest month $\left({ }^{\circ} \mathrm{C}\right)$; Tmon $10=$ the number of months with air temperature $>10{ }^{\circ} \mathrm{C}$ (unitless); MAP $=$ mean annual precipitation $(\mathrm{mm} \mathrm{y}-1)$; Psdry = precipitation in the driest month in summer $(\mathrm{mm}$ month-1); Pwdry = precipitation in the driest month in winter $(\mathrm{mm}$ month-1); Pswet $=$ precipitation in the wettest month in summer $(\mathrm{mm}$ month-1); Pwwet $=$ precipitation in the wettest month in winter $(\mathrm{mm}$ month-1); Pthreshold $=2 \times$ MAT if $>70 \%$ of precipitation falls in winter, Pthreshold $=2 \times$ MAT +28 if $>70 \%$ of precipitation falls in summer, otherwise Pthreshold $=2 \times$ MAT +14 . Summer (winter) is the 6-month period that is warmer (colder) between April-September and October-March.

\begin{tabular}{|c|c|c|c|c|}
\hline 1st & 2nd & $3 \mathrm{rd}$ & Description & Criterion \\
\hline \multirow[t]{5}{*}{ B } & & & Arid & MAP $<10 \times \mathrm{P}_{\text {threshold }}$ \\
\hline & W & & desert & MAP $<5 \times \mathrm{P}_{\text {threshold }}$ \\
\hline & $\mathrm{s}$ & & steppe & $\mathrm{MAP} \geq 5 \times \mathrm{P}_{\text {threshold }}$ \\
\hline & & $\mathrm{h}$ & hot & MAT $\geq 18$ \\
\hline & & $\mathrm{k}$ & cold & MAT $<18$ \\
\hline \multirow[t]{6}{*}{ C } & & & Temperate & Not (B) \& $T_{\text {hot }}>10 \& 0<T_{\text {cold }}<18$ \\
\hline & s & & Dry summer & $\mathrm{P}_{\text {sdry }}<40 \& \mathrm{P}_{\text {sdry }}<\mathrm{P}_{\text {wwet }} / 3$ \\
\hline & $f$ & & without dry season & Not (Cs) \\
\hline & & $\mathrm{a}$ & hot summer & $\mathrm{T}_{\text {hot }} \geq 22$ \\
\hline & & b & warm summer & Not (a) \& $T_{\text {mon } 10} \geq 4$ \\
\hline & & c & cold summer & Not $(a$ or $b) \& 1 \leq T_{\text {mon } 10}<4$ \\
\hline
\end{tabular}


https://doi.org/10.5194/soil-2021-115

Preprint. Discussion started: 12 October 2021

(c) Author(s) 2021. CC BY 4.0 License.

(c) (i)

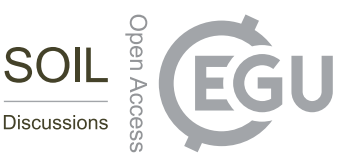

\section{Appendix E}

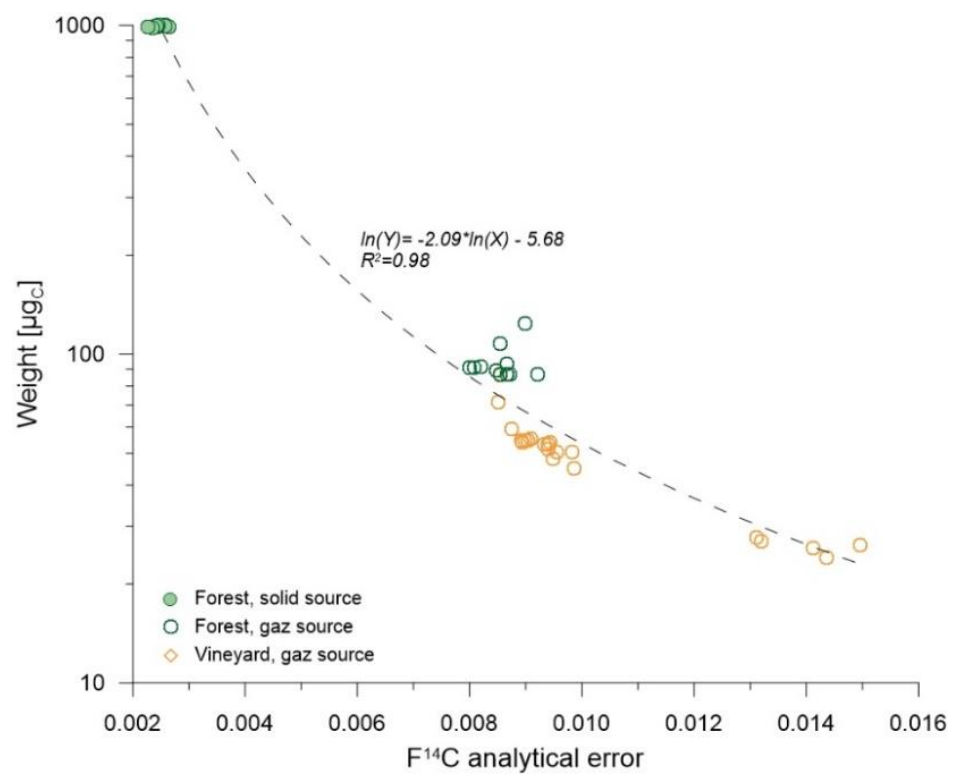

Figure E1 Influence of the carbon mass of the measured sample on the analytical error of ECHoMICADAS. The solid green circles represent soil samples obtained under the forest analyzed with the solid source, the empty green circles those analyzed with the gas source and the empty orange triangles are the soil samples obtained under vines analyzed with the gas source. 
https://doi.org/10.5194/soil-2021-115

Preprint. Discussion started: 12 October 2021

(c) Author(s) 2021. CC BY 4.0 License.

(c) (i)

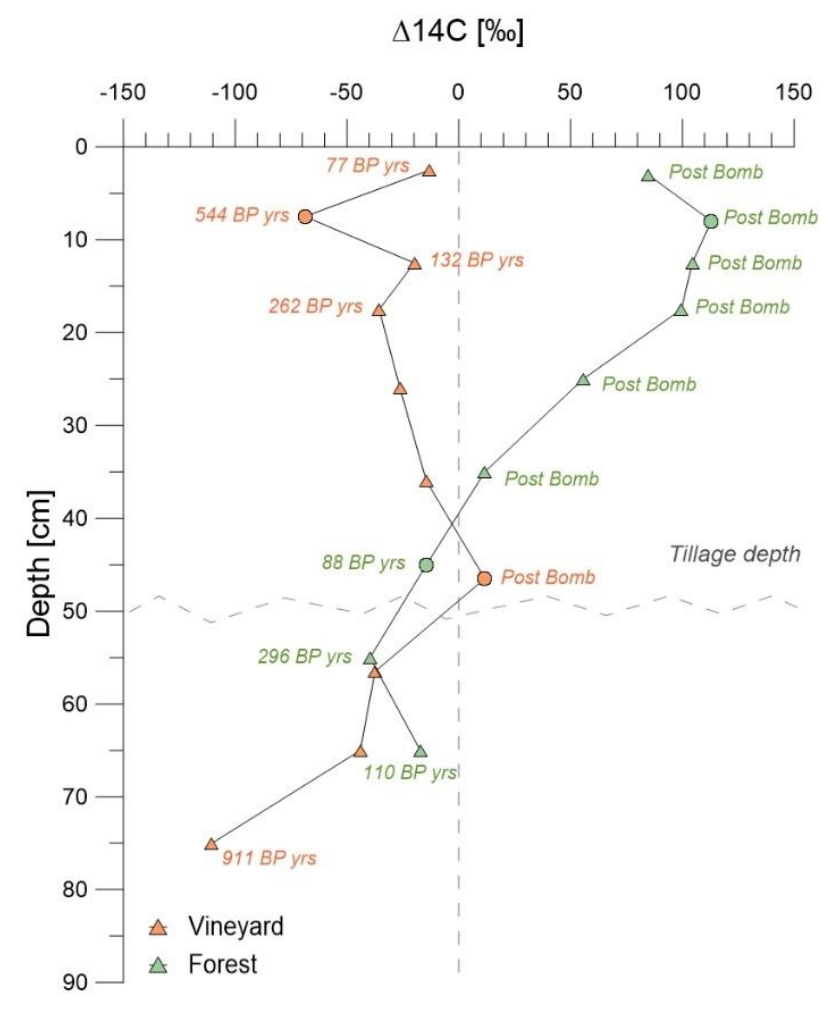

410 Figure E2 Comparison of the BP age patterns, via $\Delta^{14} \mathrm{C}[\%]$, as a function of the soil depth and vegetation cover. 


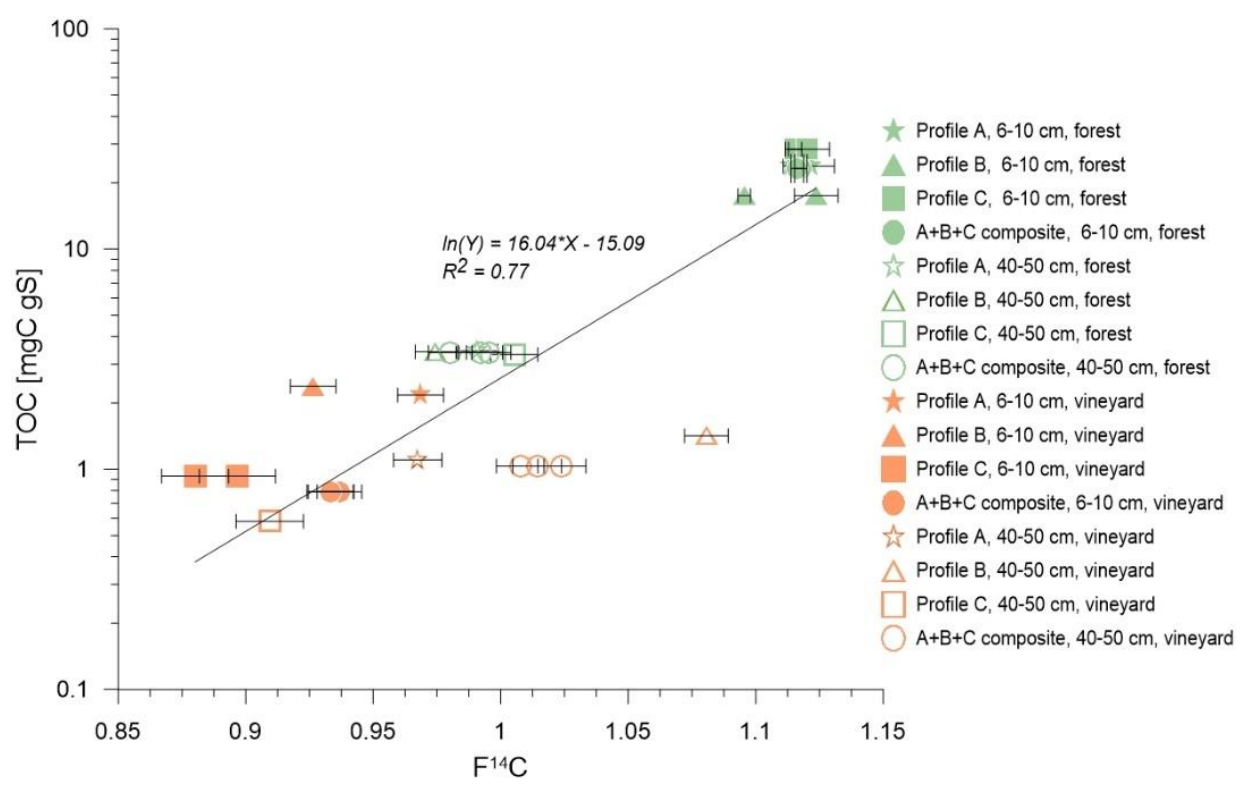

Figure E3 Variations in carbon content as a function of $\mathrm{F}^{14} \mathrm{C}$. Profiles $\mathrm{A}, \mathrm{B}$ and $\mathrm{C}$ are represented by stars, triangles and squares, respectively. These symbols are solid when they represent surface samples $(6-10 \mathrm{~cm})$ and empty when they represent deep samples $(40-50 \mathrm{~cm})$. Soil samples obtained under the forest are green and those under vines are orange. The error bars represent the analytical error. The TOC values were higher with younger $\mathrm{F}^{14} \mathrm{C}$ (usually topsoil samples): $\mathrm{R}^{2}=0.77$. Under the vineyard, ploughing had eliminated the young carbon pools.

\section{Author contributions}

The conceptualization of the study for this paper was done by SQ, CH and IBD with input from NC, FJ, DB, AD and SC. All

420 the authors participated in the collection of resources. The investigation was done by SQ, IBD and CH with substantial input from FJ, NC, AD, SC and DB. The data curation and formal analysis and methodology were done by SQ, IBD and CH. The visualization for the paper was performed by SQ, with substantial input from IBD and $\mathrm{CH}$ as well as feedback from all authors. SQ and IBD wrote the initial draft and all authors were involved in the review and editing of the paper.

\section{Competing interests}

425 The authors declare that they have no conflict of interest. 


\section{Acknowledgements}

We would like to thank Jérôme Balesdent, who sadly left us too soon, for his precious support. We would also like to thank Mr. Février and Mr. Coulomb, president of the Vignerons du Plan de la Tour cooperative, for allowing us to sample soils in their plots. Finally, we would like to thank Frédéric Guibal for his dendrochronology expertise.

\section{Financial support}

This research was funded by the ANR (NanoSoilC project ANR-16-CE01-0012-02) and supported by the University of AixMarseille. We also thank CNRS INSU for additional financial support to Solène Quero ( $\mathrm{PhD})$ in the context of the Covid-19 pandemic.

\section{References}

435 Andreetta, A., Dignac, M.-F., and Carnicelli, S.: Biological and physico-chemical processes influence cutin and suberin biomarker distribution in two Mediterranean forest soil profiles, Biogeochemistry, 112, 41-58, https://doi.org/10.1007/s10533011-9693-9, 2013.

Angers, D. A. and Eriksen-Hamel, N. S.: Full-Inversion Tillage and Organic Carbon Distribution in Soil Profiles: A MetaAnalysis, Soil Sci. Soc. Am. J., 72, 1370-1374, https://doi.org/10.2136/sssaj2007.0342, 2008.

440 Anon: ISRaD, 2020.

Baker, J. M., Ochsner, T. E., Venterea, R. T., and Griffis, T. J.: Tillage and soil carbon sequestration —What do we really know?, Agriculture, Ecosystems \& Environment, 118, 1-5, https://doi.org/10.1016/j.agee.2006.05.014, 2007.

Balesdent, J., Basile-Doelsch, I., Chadoeuf, J., Cornu, S., Derrien, D., Fekiacova, Z., and Hatté, C.: Atmosphere-soil carbon transfer as a function of soil depth, Nature, 559, 599-602, https://doi.org/10.1038/s41586-018-0328-3, 2018.

445 Basile-Doelsch, I., Brun, T., Borschneck, D., Masion, A., Marol, C., and Balesdent, J.: Effect of landuse on organic matter stabilized in organomineral complexes: A study combining density fractionation, mineralogy and $\delta 13 \mathrm{C}$, Geoderma, 151, 7786, https://doi.org/10.1016/j.geoderma.2009.03.008, 2009.

Batjes, N. H.: Total carbon and nitrogen in the soils of the world, Eur J Soil Sci, 65, 10-21, https://doi.org/10.1111/ejss.12114_2, 2014.

450 Caravaca, F., Masciandaro, G., and Ceccanti, B.: Land use in relation to soil chemical and biochemical properties in a semiarid Mediterranean environment, Soil and Tillage Research, 68, 23-30, https://doi.org/10.1016/S0167-1987(02)00080-6, 2002.

Carlisle, E. A., Steenwerth, K. L., and Smart, D. R.: Effects of Land Use on Soil Respiration: Conversion of Oak Woodlands to Vineyards, 35, 9, 2006.

Chiti, T., Certini, G., Forte, C., Papale, D., and Valentini, R.: Radiocarbon-Based Assessment of Heterotrophic Soil Respiration 
https://doi.org/10.5194/soil-2021-115

Preprint. Discussion started: 12 October 2021

(c) Author(s) 2021. CC BY 4.0 License.

(c) (i)

Conradie, W. J.: Timing of Nitrogen Fertilisation and the Effect of Poultry Manure on the Performance of Grapevines on Sandy Soil. I. Soil Analysis, Grape Yield and Vegetative Gro wth, 22, 7, 2001.

Cotrufo, M. F., Ranalli, M. G., Haddix, M. L., Six, J., and Lugato, E.: Soil carbon storage informed by particulate and mineralassociated organic matter, Nat. Geosci., 12, 989-994, https://doi.org/10.1038/s41561-019-0484-6, 2019.

460 Dimassi, B., Mary, B., Wylleman, R., Labreuche, J., Couture, D., Piraux, F., and Cohan, J.-P.: Long-term effect of contrasted tillage and crop management on soil carbon dynamics during 41 years, Agriculture, Ecosystems \& Environment, 188, 134146, https://doi.org/10.1016/j.agee.2014.02.014, 2014.

Dümig, A., Schad, P., Rumpel, C., Dignac, M.-F., and Kögel-Knabner, I.: Araucaria forest expansion on grassland in the southern Brazilian highlands as revealed by $14 \mathrm{C}$ and $\delta 13 \mathrm{C}$ studies, Geoderma, 145, 143-157, https://doi.org/10.1016/j.geoderma.2007.06.005, 2008.

Eldon, J. and Gershenson, A.: Effects of Cultivation and Alternative Vineyard Management Practices on Soil Carbon Storage in Diverse Mediterranean Landscapes: A Review of the Literature, 37, 2015.

Ellert, B. H. and Bettany, J. R.: Calculation of organic matter and nutrients stored in soils under contrasting management regimes, 75, 529-538, https://doi.org/10.4141/cjss95-075, 1995.

FAO: World reference base for soil resources 2014: international soil classification system for naming soils and creating legends for soil maps., FAO, Rome, 2014.

FAO: Food \& Agriculture Org 2018: alternative pathways to 2050., Food \& Agriculture Org, Place of publication not identified, 2018.

Fierro, A., Rutigliano, F. A., Marco, A. D., Castaldi, S., and Santo, A. V. D.: Post-fire stimulation of soil biogenic emission of CO2 in a sandy soil of a Mediterranean shrubland, Int. J. Wildland Fire, 16, 573, https://doi.org/10.1071/WF06114, 2007.

Fourie, J. C., Louw, P. J. E., Agenbag, G. A., and Infruitec-Nietvoorbij, A.: Cover crop management in a Sauvignon blanc/Ramsey vineyard in the semi- arid Olifants River Valley, South Africa. 1. Effect of management practices on selected grass and broadleaf species, 26, 9, 2005.

Guillaume, T., Bragazza, L., Levasseur, C., Libohova, Z., and Sinaj, S.: Long-term soil organic carbon dynamics in temperate cropland-grassland systems, Agriculture, Ecosystems \& Environment, 305, 107184, https://doi.org/10.1016/j.agee.2020.107184, 2021.

Harrison, K. G., Broecker, W. S., and Bonani, G.: The Effect of Changing Land Use on Soil Radiocarbon, 262, 2, 1993.

James, J. N., Gross, C. D., Dwivedi, P., Myers, T., Santos, F., Bernardi, R., Faria, M. F. de, Guerrini, I. A., Harrison, R., and Butman, D.: Land use change alters the radiocarbon age and composition of soil and water-soluble organic matter in the Brazilian Cerrado, Geoderma, 345, 38-50, https://doi.org/10.1016/j.geoderma.2019.03.019, 2019.

Jiang, Y., Luo, C., Zhang, D., Ostle, N. J., Cheng, Z., Ding, P., Shen, C., and Zhang, G.: Radiocarbon evidence of the impact of forest-to-plantation conversion on soil organic carbon dynamics on a tropical island, Geoderma, 375, 114484, https://doi.org/10.1016/j.geoderma.2020.114484, 2020.

Jreich, R.: Vertical dynamics of soil carbon - Combined use of isotopic tracers and statistical meta-analysis, Paris Saclay, Paris, 2018. 
https://doi.org/10.5194/soil-2021-115

Preprint. Discussion started: 12 October 2021

(c) Author(s) 2021. CC BY 4.0 License.

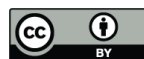

Kazlauskaite-Jadzevice, A., Tripolskaja, L., Volungevicius, J., and Baksiene, E.: Impact of land use change on organic carbon sequestration in Arenosol, AFSci, 28, https://doi.org/10.23986/afsci.69641, 2019.

Kleber, M., Eusterhues, K., Keiluweit, M., Mikutta, C., Mikutta, R., and Nico, P.: Mineral-Organic Associations: Formation, Properties, and Relevance in Soil Environments, 130, 1-140, 2015.

Kögel-Knabner, I. and Amelung, W.: Soil organic matter in major pedogenic soil groups, 384, 2021.

Lal, R.: Soil Carbon Sequestration Impacts on Global Climate Change and Food Security, Science, 304, 1623-1627, https://doi.org/10.1126/science.1097396, 2004.

Lawrence, C. R., Beem-Miller, J., Hoyt, A. M., Monroe, G., Sierra, C. A., Stoner, S., Heckman, K., Blankinship, J. C., Crow, S. E., McNicol, G., Trumbore, S., Levine, P. A., Vindušková, O., Todd-Brown, K., Rasmussen, C., Hicks Pries, C. E., Schädel,

500 C., McFarlane, K., Doetterl, S., Hatté, C., He, Y., Treat, C., Harden, J. W., Torn, M. S., Estop-Aragonés, C., Asefaw Berhe, A., Keiluweit, M., Della Rosa Kuhnen, Á., Marin-Spiotta, E., Plante, A. F., Thompson, A., Shi, Z., Schimel, J. P., Vaughn, L. J. S., von Fromm, S. F., and Wagai, R.: An open-source database for the synthesis of soil radiocarbon data: International Soil Radiocarbon Database (ISRaD) version 1.0, Earth Syst. Sci. Data, 12, 61-76, https://doi.org/10.5194/essd-12-61-2020, 2020.

López-Piñeiro, A.: Influence of the management regime and phenological state of the vines on the physicochemical properties and the seasonal fluctuations of the microorganisms in a vineyard soil under semi-arid conditions, 8, 2013.

Marschner, B. and Waldemar Wilczynski, A.: The effect of liming on quantity and chemical composition of soil organic matter in a pine forest in Berlin, Germany, Plant Soil, 137, 229-236, https://doi.org/10.1007/BF00011201, 1991.

Mary, B., Clivot, H., Blaszczyk, N., Labreuche, J., and Ferchaud, F.: Soil carbon storage and mineralization rates are affected by carbon inputs rather than physical disturbance: Evidence from a 47-year tillage experiment, Agriculture, Ecosystems \& Environment, 299, 106972, https://doi.org/10.1016/j.agee.2020.106972, 2020.

Mathieu, J. A., Hatté, C., Balesdent, J., and Parent, É.: Deep soil carbon dynamics are driven more by soil type than by climate: a worldwide meta-analysis of radiocarbon profiles, Glob Change Biol, 21, 4278-4292, https://doi.org/10.1111/gcb.13012, 2015 .

Minasny, B., Malone, B. P., McBratney, A. B., Angers, D. A., Arrouays, D., Chambers, A., Chaplot, V., Chen, Z.-S., Cheng, 515 K., Das, B. S., Field, D. J., Gimona, A., Hedley, C. B., Hong, S. Y., Mandal, B., Marchant, B. P., Martin, M., McConkey, B. G., Mulder, V. L., O’Rourke, S., Richer-de-Forges, A. C., Odeh, I., Padarian, J., Paustian, K., Pan, G., Poggio, L., Savin, I., Stolbovoy, V., Stockmann, U., Sulaeman, Y., Tsui, C.-C., Vågen, T.-G., van Wesemael, B., and Winowiecki, L.: Soil carbon 4 per mille, Geoderma, 292, 59-86, https://doi.org/10.1016/j.geoderma.2017.01.002, 2017.

Monreal, C. M., Schulten, H.-R., and Kodama, H.: Age, turnover and molecular diversity of soil organic matter in aggregates of a Gleysol, Can. J. Soil. Sci., 77, 379-388, https://doi.org/10.4141/S95-064, 1997.

Mousset, J.: Carbone des sols : enjeu pour le climat et l'agronomie, 15, 2014.

Muñoz-Rojas, M., Jordán, A., Zavala, L. M., De la Rosa, D., Abd-Elmabod, S. K., and Anaya-Romero, M.: Organic carbon stocks in Mediterranean soil types under different land uses (Southern Spain), Solid Earth, 3, 375-386, https://doi.org/10.5194/se-3-375-2012, 2012.

525 Nogales, A., Santos, E. S., Abreu, M. M., Arán, D., Victorino, G., Pereira, H. S., Lopes, C. M., and Viegas, W.: Mycorrhizal Inoculation Differentially Affects Grapevine's Performance in Copper Contaminated and Non-contaminated Soils, Front. Plant Sci., 9, 1906, https://doi.org/10.3389/fpls.2018.01906, 2019. 
https://doi.org/10.5194/soil-2021-115

Preprint. Discussion started: 12 October 2021

(c) Author(s) 2021. CC BY 4.0 License.

(c) (i)

Okur, N., Altindişli, A., Çengel, M., Göçmez, S., and Kayikçioğlu, H. H.: Microbial biomass and enzyme activity in vineyard soils under organic and conventional farming systems, 12, 2009.

530 Pellerin, S.: Stocker du carbone dans les sols français : quel potentiel au regard de l'objectif de 4 pour 1000 et à quel coût ?, INRA, 2019.

Pinzari, F., Trinchera, A., Benedetti, A., and Sequi, P.: Use of biochemical indices in the mediterranean environment: comparison among soils under different forest vegetation, Journal of Microbiological Methods, 36, 21-28, https://doi.org/10.1016/S0167-7012(99)00007-X, 1999.

535 Poeplau, C. and Don, A.: Sensitivity of soil organic carbon stocks and fractions to different land-use changes across Europe, 192, 189-201, 2013.

Poeplau, C., Vos, C., and Don, A.: Soil organic carbon stocks are systematically overestimated by misuse of the parameters bulk density and rock fragment content, SOIL, 3, 61-66, https://doi.org/10.5194/soil-3-61-2017, 2017.

Ramesh, T., Bolan, N. S., Kirkham, M. B., Wijesekara, H., Kanchikerimath, M., Srinivasa Rao, C., Sandeep, S., Rinklebe, J.,

540 Ok, Y. S., Choudhury, B. U., Wang, H., Tang, C., Wang, X., Song, Z., and Freeman II, O. W.: Soil organic carbon dynamics: Impact of land use changes and management practices: A review, in: Advances in Agronomy, vol. 156, Elsevier, 1-107, https://doi.org/10.1016/bs.agron.2019.02.001, 2019.

Reimer, P. J., Brown, T. A., and Reimer, R. W.: Discussion: Reporting and Calibration of Post-Bomb 14C Data, Radiocarbon, 46, 1299-1304, https://doi.org/10.1017/S0033822200033154, 2004.

545 Rubel, F. and Kottek, M.: Observed and projected climate shifts 1901-2100 depicted by world maps of the Köppen-Geiger climate classification, MetZ, 19, 135-141, https://doi.org/10.1127/0941-2948/2010/0430, 2010.

Shi, Z., Allison, S. D., He, Y., Levine, P. A., Hoyt, A. M., Beem-Miller, J., Zhu, Q., Wieder, W. R., Trumbore, S., and Randerson, J. T.: The age distribution of global soil carbon inferred from radiocarbon measurements, Nat. Geosci., https://doi.org/10.1038/s41561-020-0596-z, 2020.

550 Stuiver, M. and Polach, H. A.: Discussion Reporting of 14C Data, Radiocarbon, 19, 355-363, https://doi.org/10.1017/S0033822200003672, 1977.

Trumbore, S.: Radiocarbon and Soil Carbon Dynamics, Annu. Rev. Earth Planet. Sci., 37, 47-66, https://doi.org/10.1146/annurev.earth.36.031207.124300, 2009.

Trumbore, S. E.: Comparison of carbon dynamics in tropical and temperate soils using radiocarbon measurements, Global

Biogeochem. Cycles, 7, 275-290, https://doi.org/10.1029/93GB00468, 1993.

Tsozué, D., Nafissa, B., Basga, S. D., and Balna, J.: Soil change in Arenosols under long term cultivation in the sudanosahelian zone of Cameroon, Geoderma Regional, 23, e00338, https://doi.org/10.1016/j.geodrs.2020.e00338, 2020.

Vittori Antisari, L., Laudicina, V. A., Falsone, G., Carbone, S., Badalucco, L., and Vianello, G.: Native and planted forest species determine different carbon and nitrogen pools in Arenosol developed on Holocene deposits from a costal Mediterranean area (Tuscany, Italy), Environ Earth Sci, 75, 776, https://doi.org/10.1007/s12665-016-5581-x, 2016.

van der Voort, T. S., Hagedorn, F., McIntyre, C., Zell, C., Walthert, L., Schleppi, P., Feng, X., and Eglinton, T. I.: Variability in $14 \mathrm{C}$ contents of soil organic matter at the plot and regional scale across climatic and geologic gradients, Biogeosciences, 13, 3427-3439, https://doi.org/10.5194/bg-13-3427-2016, 2016. 
https://doi.org/10.5194/soil-2021-115

Preprint. Discussion started: 12 October 2021

(c) Author(s) 2021. CC BY 4.0 License.

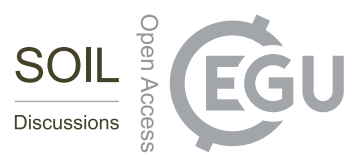

Wacker, L., Němec, M., and Bourquin, J.: A revolutionary graphitisation system: Fully automated, compact and simple, 565 Nuclear Instruments and Methods in Physics Research Section B: Beam Interactions with Materials and Atoms, 268, 931-934, https://doi.org/10.1016/j.nimb.2009.10.067, 2010.

Wang, Y., Amundson, R., and Trumbore, S.: The impact of land use change on C turnover in soils, Global Biogeochem. Cycles, 13, 47-57, https://doi.org/10.1029/1998GB900005, 1999. 